\title{
Burning of olive tree branches: a major organic aerosol source in the Mediterranean
}

\author{
E. Kostenidou ${ }^{1}$, C. Kaltsonoudis ${ }^{1,2}$, M. Tsiflikiotou ${ }^{1,2}$, E. Louvaris ${ }^{1,2}$, L. M. Russell ${ }^{4}$, and S. N. Pandis ${ }^{1,2,3}$ \\ ${ }^{1}$ Institute of Chemical Engineering Sciences, ICE-HT, Patras, Greece \\ ${ }^{2}$ Department of Chemical Engineering, University of Patras, Patras, Greece \\ ${ }^{3}$ Department of Chemical Engineering, Carnegie Mellon University, Pittsburgh, USA \\ ${ }^{4}$ Scripps Institute of Oceanography, University of California, San Diego, 92093, USA
}

Correspondence to: S. N. Pandis (spyros@chemeng.upatras.gr)

Received: 23 February 2013 - Published in Atmos. Chem. Phys. Discuss.: 19 March 2013

Revised: 10 July 2013 - Accepted: 18 July 2013 - Published: 3 September 2013

\begin{abstract}
Aerosol produced during the burning of olive tree branches was characterized with both direct source sampling (using a mobile smog chamber) and with ambient measurements during the burning season. The fresh particles were composed of $80 \%$ organic matter, 8-10\% black carbon (BC), $5 \%$ potassium, 3-4\% sulfate, $2-3 \%$ nitrate and $0.8 \%$ chloride. Almost half of the fresh olive tree branches burning organic aerosol (otBB-OA) consisted of alkane groups. Their mode diameter was close to $70 \mathrm{~nm}$. The oxygen to carbon $(\mathrm{O}: \mathrm{C})$ ratio of the fresh otBB-OA was $0.29 \pm 0.04$. The mass fraction of levoglucosan in $\mathrm{PM}_{1}$ was 0.034-0.043, relatively low in comparison with most fuel types. This may lead to an underestimation of the otBB-OA contribution if levoglucosan is being used as a wood burning tracer. Chemical aging was observed during smog chamber experiments, as $f_{44}$ and $\mathrm{O}: \mathrm{C}$ ratio increased, due to reactions with $\mathrm{OH}$ radicals and $\mathrm{O}_{3}$. The otBB-OA AMS mass spectrum differs from the other published biomass burning spectra, with a main difference at $m / z 60$, used as levoglucosan tracer. In addition to particles, volatile organic compounds (VOCs) such as methanol, acetonitrile, acrolein, benzene, toluene and xylenes are also emitted. Positive matrix factorization (PMF) was applied to the ambient organic aerosol data and 3 factors could be identified: OOA (oxygenated organic aerosol, $55 \%$ ), HOA (hydrocarbon-like organic aerosol, 11.3\%) and otBB-OA $33.7 \%$. The fresh chamber otBB-OA AMS spectrum is close to the PMF otBB-OA spectrum and resembles the ambient mass spectrum during olive tree branches burning periods. We estimated an otBB-OA emission factor of $3.5 \pm 0.9 \mathrm{~g} \mathrm{~kg}^{-1}$. Assuming that half of the olive tree branches
\end{abstract}

pruned is burned in Greece, $2300 \pm 600$ tons of otBB-OA are emitted every year. This activity is one of the most important fine aerosol sources during the winter months in Mediterranean countries.

\section{Introduction}

In all, $95 \%$ of the global biomass burning is anthropogenic resulting from efforts to clear land, convert forests to agricultural and pastoral lands, heat residences and dispose agricultural waste (Crutzen and Andreae, 1990; Schüle, 1990; Andreae and Merlet, 2001). Biomass burning can contribute up to $90 \%$ of fine particulate matter in the burning season in the Amazon (Yamasoe et al., 2000). During the winter, biomass combustion is one of the major sources of organic aerosol in large parts of Europe (Puxbaum et al., 2007). The release height of the emissions is low and the mixing during the winter months is often weak, leading to the deterioration of local air quality and visibility and an increase in the risk of adverse effects on human health especially in populated areas (Lighty et al., 2000; Boman et al., 2003; Naeher et al., 2007). Biomass burning particles also affect earth's albedo (Crutzen and Andreae, 1990; Andreae, 1995) and can act as cloud condensation nuclei (CCN), modifying the cloud droplet size distribution and therefore the reflectivity of clouds (Rogers et al., 1991; Roberts et al., 2002).

Numerous laboratory-based studies have been conducted for the physical and chemical characterization of biomass combustion aerosol (e.g., Shafizadeh, 1984; Abas et al., 
1995; Simoneit et al., 1999; Hennigan et al., 2010). The fresh biomass burning particles are in the submicron size range and consist of approximately $80 \%$ organic compounds, 5-10\% $\mathrm{BC}$ and $10-15 \%$ inorganic salts (potassium, sulfate, chloride and nitrate) (Reid et al., 2005). The most abundant individual compound identified by GC-MS analysis is levoglucosan (1,6-anhydro- $\beta$-D-glucopyranose, $\mathrm{C}_{6} \mathrm{H}_{10} \mathrm{O}_{5}$ ), a product of cellulose thermal decomposition (Shafizadeh and Fu, 1973; Shafizadeh et al., 1979, 1984). Schneider et al. (2006) reported that AMS mass spectra of beech, oak, musasa, spruce and savanna grass burning are dominated by hydrocarbon fragment ions $\mathrm{C}_{n} \mathrm{H}_{2 n-1}^{+}(m / z=27,41,55,69, \ldots)$, $\mathrm{C}_{n} \mathrm{H}_{2 n+1}^{+}(m / z=29,43,57, \ldots)$ and $\mathrm{C}_{n} \mathrm{H}_{2 n-3}^{+}(m / z=67$, $81,95, \ldots$ ). These mass spectra contained characteristic levoglucosan markers at $m / z 60(0.7-4.4 \%$ of the total organic signal) and at $m / z 73(0.8-2.2 \%$ of the total organic signal). Weimer et al. (2008) found that during the smoldering phase the biomass burning particles are dominated by oxygenated species and they proposed the mass fragments 29,60 and 73 as levoglucosan signatures. A number of organic vapours are emitted during biomass burning, together with the particles. For example during laboratory biomass burning, Christian et al. (2003) quantified the emissions of gases such as acetaldehyde, phenol, acetol, glycolaldehyde, acetone, furan, acetonitrile, toluene and benzene.

Several ground and aircraft campaigns have focused on biomass burning (e.g., Fang et al., 1999; Hudson et al., 2004; Crounse et al., 2009; Yokelson et al., 2009; Pratt et al., 2011). Anydrosugars such as levoglucosan, manosan, galactosan, aribinosan and xylosan have been identified by GC-MS in aqueous extracts of aerosol samples from pasture and rainforest sites in Rondônia, Brazil (Graham et al., 2002). Alfarra et al. (2007) suggested the mass fragments 60,73 and 137 as AMS marker fragments for wood burning aerosols based on measurements in Switzerland. Elsasser et al. (2012) indicated a high correlation between the wood combustion organic aerosol factor using positive matrix factorization (PMF) and the levoglucosan measured with one-hour resolution $\mathrm{PM}_{1}$ filters by GC-MS during winter measurements in Augsburg, Germany. During airborne measurements of the savanna fires in Africa (Yokelson et al., 2003) numerous gas phase compounds were identified, among them $\mathrm{CO}$, methane, methanol, formaldehyde, formic acid, acetic acid, etc.

The emission factors, EFs, of biomass burning compounds have been estimated in various studies. Sinha et al. (2003) found that the EF of the organic particulate carbon during savanna fires in southern Africa was $2.3 \pm 1.2 \mathrm{~g} \mathrm{C} \mathrm{kg}^{-1}$ and that the major organic emitted gas-phase compound was acetic acid with $\mathrm{EF}=2.4 \pm 0.9 \mathrm{~g} \mathrm{~kg}^{-1}$. In the same study the EF of the number of particles from 0.1 to $3 \mu \mathrm{m}$ was $2.0 \pm 1.5 \times 10^{14} \mathrm{~kg}^{-1}$ of fuel burned. The EFs of toluene and benzene have been reported to be in the $0.13-0.79$ and 0.18 $0.24 \mathrm{~g} \mathrm{~kg}^{-1}$ range, respectively (Andeae and Merlet, 2001; Sinha et al., 2003; Christian et al., 2003). CO is also one of the most abundant compounds emitted during biomass burning fires. The reported EFs values are in the range 65$137 \mathrm{~g} \mathrm{~kg}^{-1}$ (Andeae and Merlet, 2001; Christian et al., 2003; Yokelson et al., 2009).

The majority of the previous studies have focused on either wild fires or on combustion of wood that is used for residential heating during the winter. However, there is little information in the literature about burning of agricultural waste and more specifically olive tree branches burning. Burning of olive tree branches is a common agricultural waste management technique after the pruning of olive trees during the months November to February. Almost 1 billion (90\%) of the olive trees on our planet are located around the Mediterranean. Forty years ago Darley et al. (1974) estimated that the EF of olive tree wood burning of fine PM is around $5 \mathrm{~g} \mathrm{~kg}^{-1}$. Using Greece as an example (132 million olive trees) and assuming that around $10 \mathrm{~kg}$ of branches are pruned from one olive tree, 6600 tons of fine PM will be emitted in a 3-4 month period in Greece. This can be compared with the 150 tons of fine PM per year emitted by the 5000000 passenger cars in Greece (assuming an emission of $30 \mathrm{~g}$ of fine PM per car per year based on the EPA (2005) emission factors). As a result, emissions due to olive tree branches burning in Greece and the Mediterranean area can be a major source of fine aerosols during the late fall and winter.

The present work will focus on the characterization of both particles and vapors emitted during olive tree branches burning and the quantification of the corresponding emissions. We will combine source sampling and characterization (including chemical aging of the emissions in a smog chamber) with field measurements during the burning season.

\section{Experimental procedure}

\subsection{Source sampling - chamber experiments}

Four olive tree branches burning experiments (Table 1) were carried out in the Institute of Chemical Engineering Sciences (ICE-HT) campus. Approximately $15 \mathrm{~kg}$ of branches from the nearby fields were used for each experiment. The fire was initiated using a butane torch and a pile of approximately $5 \mathrm{~kg}$ of branches. The rest of the branches were gradually added to the fire mimicking the procedure used by farmers. In experiment 4 a piece of plastic was burned together with the branches, something that often happens during the field fires. A $10 \mathrm{~m}^{3}$ Teflon chamber was filled with smoke for 15-20 min using insulated 0.5 in copper tubing and a pump (model MB 602, Metal Bellow). After partial filling, the chamber was moved back to the laboratory where its contents were diluted by a factor of 10 to 25 with particle and pollutant free air until its volume reached $10 \mathrm{~m}^{3}$. A suite of instrumentation was then used for the characterization of the particle and gas phase for $10-20 \mathrm{~h}$. The sampled aerosol was not dried. 
Table 1. Conditions for chamber experiments.

\begin{tabular}{|c|c|c|c|c|c|c|}
\hline $\begin{array}{l}\text { Experiment } \\
\text { number }\end{array}$ & Date & $\begin{array}{l}\text { Addition } \\
\text { of plastic }\end{array}$ & $\begin{array}{l}\text { Age of olive } \\
\text { tree branches }\end{array}$ & $\begin{array}{l}\text { Initial mass concentration } \\
\qquad\left(\mu \mathrm{g} \mathrm{m}^{-3}\right)\end{array}$ & $\begin{array}{l}\text { Initial } \mathrm{O}_{3}^{*} \\
\quad(\mathrm{ppb})\end{array}$ & $\begin{array}{c}\mathrm{OH} \\
\left(\text { molecules } \mathrm{cm}^{-3}\right)\end{array}$ \\
\hline 1 & $\begin{array}{c}14 \text { Dec } 2011 \\
\text { Day }\end{array}$ & & Fresh/dry & 58 & 80 & NA \\
\hline 2 & $\begin{array}{l}19 \text { Dec } 2011 \\
\text { Day }\end{array}$ & & Fresh/wet & 47 & 230 & $1 \times 10^{6}$ \\
\hline 3 & $\begin{array}{c}10 \text { Feb } 2012 \\
\text { Day }\end{array}$ & & 2 months old/dry & 67 & 45 & $0.8 \times 10^{6}$ \\
\hline 4 & $\begin{array}{c}17 \text { Feb } 2012 \\
\text { Night }\end{array}$ & $\mathrm{x}$ & 2 months old/dry & 55 & 70 & $0.4 \times 10^{6}$ \\
\hline
\end{tabular}

* The ozone presented here is produced during the fire.

\subsection{Instrumentation}

\subsubsection{HR-ToF-AMS}

The size-resolved chemical composition of the aerosol was monitored using a High Resolution Time-of-Flight Aerosol Mass Spectrometer (HR-ToF-AMS) from Aerodyne Research Inc. (DeCarlo et al., 2006). The HR-AMS measures only the non-refractory $\mathrm{PM}_{1}$ species. The vaporizer temperature was set at $600^{\circ} \mathrm{C}$ and the tungsten filament for electron ionization was run at an accelerating voltage of $70 \mathrm{eV}$. The HR-AMS run alternatively between V-mode (single stage reflectron) and $\mathrm{W}$-mode (double stage reflectron) with $3 \mathrm{~min}$ of measuring time for each mode. In this paper the $\mathrm{V}$-mode data are presented.

\subsubsection{PTR-MS}

A Proton Transfer Reaction Mass Spectrometer (PTR-MS, Ionicon Analytik) was used for the characterization of the volatile organic compounds (VOCs). The PTR-MS sampled continuously in the selected mass scan mode (23-42 masses were selected) with a total sample time of 6-10 s. A Teflon filter (Whatman PTFE $0.2 \mu \mathrm{m}$ ) was installed before the inlet tube in order to minimize the particles entering the instrument. The inlet tube was at $60^{\circ} \mathrm{C}$ and the same temperature was used for the reaction chamber. The drift tube pressure was 2.2 mbar and the voltage applied was $600 \mathrm{~V}$. For the calibrations a standard mixture of 17 VOCs (Ionicon Analytik) was used.

\subsubsection{SMPS}

A Scanning Mobility Particle Sizer (SMPS, classifier model 3080, DMA model 3081, CPC model 3775 or 3787, TSI) operated at a sheath flow rate of $5 \mathrm{~L} \mathrm{~min}^{-1}$ and a sample flow rate of $1 \mathrm{~L} \mathrm{~min}^{-1}$. The SMPS measured the number size distribution in the $10-500 \mathrm{~nm}$ range.

\subsubsection{MAAP}

A Multiple-Angle Absorption Photometer (MAAP, Thermo Scientific Inc.) was used during 2 chamber experiments for the BC measurement. The MAAP measures the amount of light (wavelength $637 \mathrm{~nm}$ ) that is transmitted and scattered back from a particle laden glass fibre filter (Petzold and Schönlinner, 2004).

\subsubsection{Gas monitors}

A suite of gas monitors was used for the measurement of the $\mathrm{NO}_{\mathrm{x}}, \mathrm{O}_{3}, \mathrm{CO}$ and $\mathrm{CO}_{2}$ concentrations (Teledyne, models T201, 400E, 300E and T360, respectively). A series of gas standards (Air Liquid) was used for the calibration.

\subsubsection{GC-MS}

For some chamber experiments Teflon filters (Whatman PTFE, $0.2 \mu \mathrm{m}, 47 \mathrm{~mm}$ ), Quartz (Pall Tissuguartz, $47 \mathrm{~mm}$ ) and high volume Quartz filters (Whatman QMA, $101.6 \mathrm{~mm}$ ) were collected. For the $47 \mathrm{~mm}$ filters a sampler equipped with a $\mathrm{PM}_{2.5}$ inlet was used (MetOne SuperSASS) and for the $101.6 \mathrm{~mm}$ filters a high volume sampler $\left(220 \mathrm{~L} \mathrm{~min}^{-1}\right.$, Tisch Environmental) was used. The corresponding samples were analyzed by gas chromatography mass spectroscopy (GCMS, Shimadzu QP2010 Ultra) and the levoglucosan concentration was quantified. The extraction procedure and analysis conditions are similar to that of Simpson et al. (2004). Details for the analysis are included in the Supplement.

\subsubsection{FTIR}

During two experiments filters for Fourier Transform Infrared Spectroscopy (FTIR) functional group analysis were collected directly from the fire and from the chamber after dilution (Maria et al., 2003; Gilardoni et al., 2007). The samples were analyzed using an FTIR Spectrometer (Bruker Tensor 27 spectrometer with DTGS detector). FTIR spectra were collected by averaging 128 absorbance scans at wavenumbers from 400 to $4000 \mathrm{~cm}^{-1}$ with a resolution of $2 \mathrm{~cm}^{-1}$. The 
filters were scanned prior to use, and these spectra were subtracted from the spectra obtained after sampling. More information about the method followed can be found in Maria et al. (2002).

\subsection{Ambient measurements}

Sampling of ambient aerosols was conducted in the area of the ICE-HT Institute, which is located $8 \mathrm{~km}$ east of Patras and is surrounded by olive tree fields. The measurements took place from November 2011 to February 2012 (olive tree branches burning period) with sampling over a total of 20 days. The instrumentation used has been described in Sect. 2.2 and included the HR-AMS, the PTR-MS, the SMPS, the MAAP and the $\mathrm{NO}_{\mathrm{x}}, \mathrm{O}_{3}, \mathrm{CO}$ and $\mathrm{CO}_{2}$ monitors. No Nafion dryer was used prior to the sampling.

\subsection{Data analysis}

HR-AMS data analysis was performed using the standard HR-AMS data analysis software SQUIRREL v1.51C and PIKA v1.10C (Sueper, 2011) with Igor Pro 6.22A (Wavemetrics). For the HR-AMS organic mass spectra, we used the fragmentation table of Aiken et al. (2008) with the following modifications at $m / z$ 's 28 and 18 . The $m / z 28$ may include contributions from both the gas and particle phase. The PToF spectra of $m / z 28$ showed that there was a large air beam signal (from $\mathrm{N}_{2}^{+}$). However, there was no clear organic particulate signal. The signal of the particulate phase was very noisy, so the organic aerosol contribution at $\mathrm{m} / \mathrm{z} 28$ was set to zero. The $m / z 18$ may be influenced by water and organic compounds. The organic aerosol (OA) at $m / z 18$ was set equal to the OA signal at $m / z 44$, because the size distribution of the $m / z 18$ was similar with the size distribution of $m / z 44$, though noisier. Using this modification the particle bound water signal was positive.

During the chamber experiments the species measured by the HR-AMS were organics, sulfate, nitrate, chloride and potassium. However, the HR-AMS can only detect a fraction of the potassium, and thus only the relative values are reliable. Using the $\mathrm{BC}$ concentrations measured by the MAAP, we estimated the $\mathrm{BC}$ mass distributions assuming a size - independent $\mathrm{OA} / \mathrm{BC}$ ratio. Applying the algorithm of Kostenidou et al. (2007), we estimated a collection efficiency (CE) of $0.6 \pm 0.05$ for the chamber experiments. This is consistent with other biomass burning CE estimations (Huffman et al., 2005; Capes et al., 2008). We confirmed that this value was appropriate for our ambient measurements (during which biomass burning was a major source) by comparing the SMPS volume concentration with the estimated volume concentration based on the AMS measurements. This consistency check can be found in the Supplement.

PMF (Paatero and Tapper, 1994; Lanz et al., 2007) is a bilinear unmixing model used to describe the measurements as a linear combination of factors. The model solves the prob- lem: $\mathbf{X}=\mathbf{G F}+\mathbf{E}$, where $\mathbf{X}$ is a $a \times b$ matrix of the organic mass spectra for $a$ time periods and with $b \mathrm{~m} / \mathrm{z}$ 's, $\mathbf{F}$ is an $p \times b$ matrix with $p$ profile factors (which are constant mass spectra), $\mathbf{G}$ is a $a \times p$ matrix with the corresponding contribution of each factor and $\mathbf{E}$ is an $a \times b$ matrix of the residuals. PMF minimizes the sum of the squared and uncertaintyscaled residuals and then the $\mathbf{G}$ and $\mathbf{F}$ are fit (Paatero and Tapper, 1994). In this work we applied PMF to the ambient measured AMS organic mass spectra. As inputs we used data from 20 days from November 2011 to February 2012, when olive tree branches fires were observed. PMF was applied for the $m / z$ 's 12-200 to both unit mass resolution (UMR) and high resolution (HR) organic mass spectra, following the approach of Ulbrich et al. (2009).

\section{Olive branches burning aerosol characterization}

\subsection{Chemical composition}

The fresh particles consisted of $80 \%$ organic matter, 8$10 \% \mathrm{BC}, 5 \%$ potassium, $3-4 \%$ sulfate, $2-3 \%$ nitrate, $0.8 \%$ chloride and practically zero ammonium. For experiment 4, where plastic was burned together with the olive tree branches the $\mathrm{CE}$ was lower $(0.45 \pm 0.04)$ and the particle composition was different: $52 \%$ organic matter, $5 \%$ BC, $8 \%$ potassium, $3 \%$ sulfate, $2 \%$ nitrate, $21 \%$ chloride and $9 \%$ ammonium.

The $\mathrm{O}: \mathrm{C}$ ratio of fresh otBB-OA was estimated using the first hour of each experiment. It was on average $0.29 \pm 0.04$ which is close to the middle of the literature range $0.14-0.42$ (Schneider et al., 2006; Weimer et al., 2008). Organonitrate compounds were also detected but with a low contribution of $5 \pm 1 \%$ of the organic mass. The presence of the organonitrates did not have a major impact (1-2\% difference) on the $\mathrm{O}: \mathrm{C}$ ratio.

The composition estimated based on FTIR analysis (experiment 2) indicates that the otBB-OA was composed of approximately $49 \%$ alkane groups $\left(\sim 2920 \mathrm{~cm}^{-1}\right), 28 \%$ organic hydroxyl groups $\left(\sim 3350 \mathrm{~cm}^{-1}\right), 10 \%$ carboxylic acids (1720 and $\sim 2800 \mathrm{~cm}^{-1}$ ), $10 \%$ primary amine groups $\left(1625 \mathrm{~cm}^{-1}\right)$, and $3 \%$ carbonyl groups $\left(1720 \mathrm{~cm}^{-1}\right)$, with fractions calculated by organic mass rather than moles (Fig. S1). The normalized FTIR spectrum is shown in Fig. 1. Comparison with FTIR spectra from other BB-OA sources (Mexico City, Paseo de Cortez and Houston; Fig. 1) indicates that the otBB-OA spectrum has substantially higher organic hydroxyl group concentration and substantially lower carbonyl group. The higher hydroxyl group in the fresh otBB-OA is consistent with a contribution from vegetative detritus (consisting of cellulose) (Liu et al., 2012). The lower carbonyl groups in the fresh BBOA are also expected, as atmospheric processing of biomass burning aerosol has been shown to increase ketone groups and decrease hydroxyl groups (Hawkins and Russell, 2010). In addition, the 


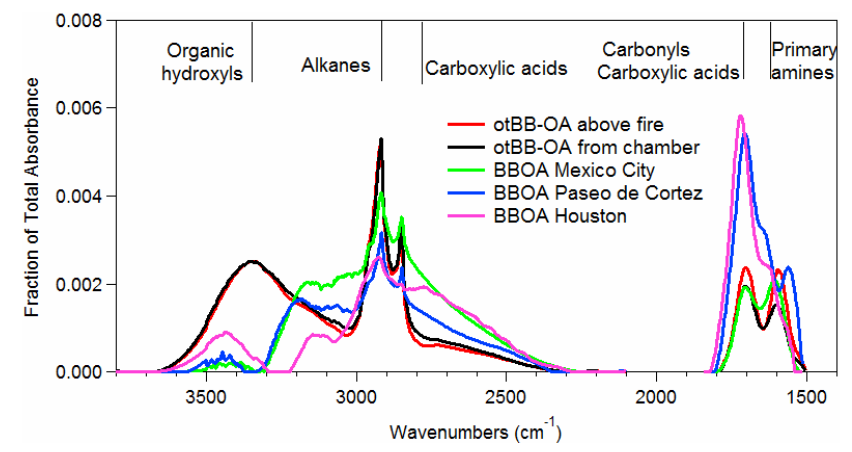

Fig. 1. Normalized FTIR spectra for experiment 2 for the sample taken directly from the olive tree branches fire (red line) and from the chamber the first hour of the experiment (black line). The two mass spectra are similar to each other. The otBB-OA spectrum differs a lot from other BBOA FTIR spectra measured in Mexico City, Paseo de Cortez and Houston (Liu et al., 2009; Russell et al., 2009). The correlation coefficients are $R^{2}=0.34,0.29$ and 0.21 , respectively.

differences in the alkane group region are expected given that the biomass burned in Mexico and Texas did not include olive trees and thus the produced aerosol will have different signatures. As a result, the fresh otBB-OA has a weak correlation (Fig. 1) with BBOA measured in Mexico City $\left(R^{2}=0.34\right)$, at Paseo de Cortez $\left(R^{2}=0.29\right)$, and at Houston $\left(R^{2}=0.21\right)$ (Liu et al., 2009; Russell et al., 2009).

Teflon $\mathrm{PM}_{2.5}$ and Quartz total PM filters were analyzed by GC-MS for the measurement of levoglucosan. For the Teflon filters the ratio of levoglucosan to $\mathrm{PM}_{2.5}$ mass was 0.027 0.035 and for the Quartz filters the ratio of levoglucosan to total PM mass was 0.017-0.025. Calculating the OC from the AMS the levoglucosan to $\mathrm{PM}_{1}$ OC mass ratio was between 0.034 and 0.043 . For hardwood and softwood combustion the reported levoglucosan/OC ratios are between 0.01 and 0.334 (Fine et al., 2002, 2004). Puxbaum et al. (2007) reported a levoglucosan/OC ratio of 0.08 for beech wood and 0.21 for spruce wood. The levoglucosan/OC ratio for oak was around 0.06 (Sullivan et al., 2008). The ratio measured for the olive tree braches is close to the lower limit of the above reported values. This implies that otBB-OA contains less levoglucosan than BBOA from burning of most other types of wood or vegetation.

The average normalized organic mass spectra of the four olive tree branches burns at the beginning of the sampling are shown in Fig. 2. The mass spectrum was characterized mostly by $m / z$ 's $27,29,39,41,43,44,55,57,67$, 69 and 91. High resolution mass spectra analysis showed the co-existence of hydrocarbon fragment ions and oxygenated species for the homologous chains $\mathrm{C}_{n} \mathrm{H}_{2 n-1}^{+}$and $\mathrm{C}_{n} \mathrm{H}_{2 n-3} \mathrm{O}^{+}$at $m / z=41,55,69$ and the homologous chains $\mathrm{C}_{n} \mathrm{H}_{2 n+1}^{+}$and $\mathrm{C}_{n} \mathrm{H}_{2 n-1} \mathrm{O}^{+}$at $m / z=29,43,57$. The contribution of the $\mathrm{C}_{x} \mathrm{H}_{y}$ family species was higher. For example at $m / z$ 's $41,43,55,57$ and 69 the hydrocarbon contri-
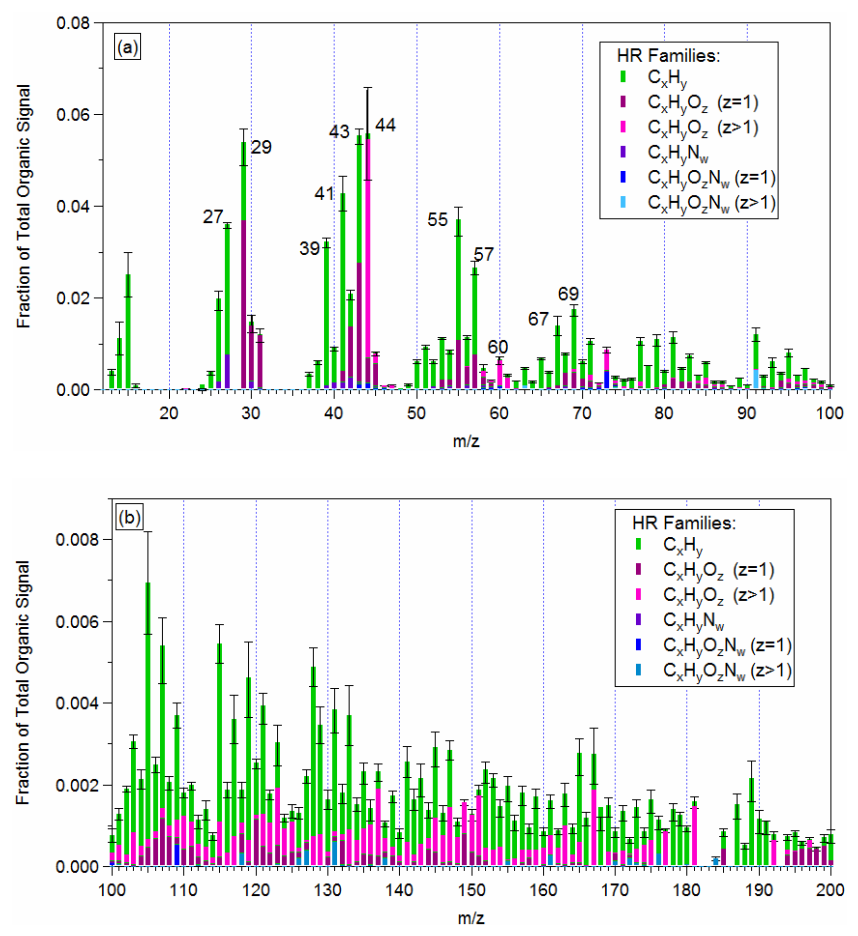

Fig. 2. Average of fresh organic mass spectra of the four source characterization experiments: (a) the mass spectra from $m / z$ 's 1 to 100 and (b) from $m / z$ 's 101 to 200 . The black bars correspond to one standard deviation of the total amount at each $\mathrm{m} / \mathrm{z}$.

bution was $94 \%, 51 \%, 71 \%, 71 \%$ and $78 \%$, respectively, while the oxygenated compounds were $6 \%, 49 \%, 29 \%$, $29 \%$ and $22 \%$ accordingly. The signal of the $m / z 44\left(\mathrm{CO}_{2}^{+}\right)$, which is a marker for OOA (Zhang et al., 2005), was pronounced in the mass spectrum. The sampled otBB-OA included particles produced during both the flaming and smoldering phases. Weimer et al. (2008) found that the flaming phase was dominated by hydrocarbon fragment ions such as $\mathrm{C}_{n} \mathrm{H}_{2 n-1}^{+}(m / z=27,41,55,69$, etc. $)$ and $\mathrm{C}_{n} \mathrm{H}_{2 n+1}^{+}(m / z=$ $29,43,57,71$, etc.) while the smoldering stage had much higher $\mathrm{CO}_{2}^{+}$contribution. In experiment $2, m / z$ 44 was quite lower than $m / z 43$ probably because during this experiment the contribution of the flaming phase was higher. This explanation is also supported by the increased NO (around 510 times higher) and acetonitrile (approximately 11 times higher) emissions (Lobert et al., 1990), in comparison with the other experiments. There was also signal above $m / z 101$ with characteristic peaks at $m / z 105,107,115$, etc. (Fig. 2b). The organic signal in the $101-200 \mathrm{~m} / z$ range accounted for $18 \%$ of the total and there was not much variation (15-20\%) among the four experiments. The levoglucosan markers $\mathrm{m} / \mathrm{z}$ $60\left(\mathrm{C}_{2} \mathrm{H}_{4} \mathrm{O}_{2}^{+}\right)$and $m / z 73\left(\mathrm{C}_{3} \mathrm{H}_{5} \mathrm{O}_{2}^{+}\right)$(Schneider et al., 2006) were low $(0.65 \%$ and $0.76 \%$ correspondingly) in all experiments. The contribution of $\mathrm{C}_{2} \mathrm{H}_{4} \mathrm{O}_{2}^{+}$and $\mathrm{C}_{3} \mathrm{H}_{5} \mathrm{O}_{2}^{+}$to the organic signal at $m / z$ 's 60 and 73 was around $90 \%$ and $60 \%$, respectively. 


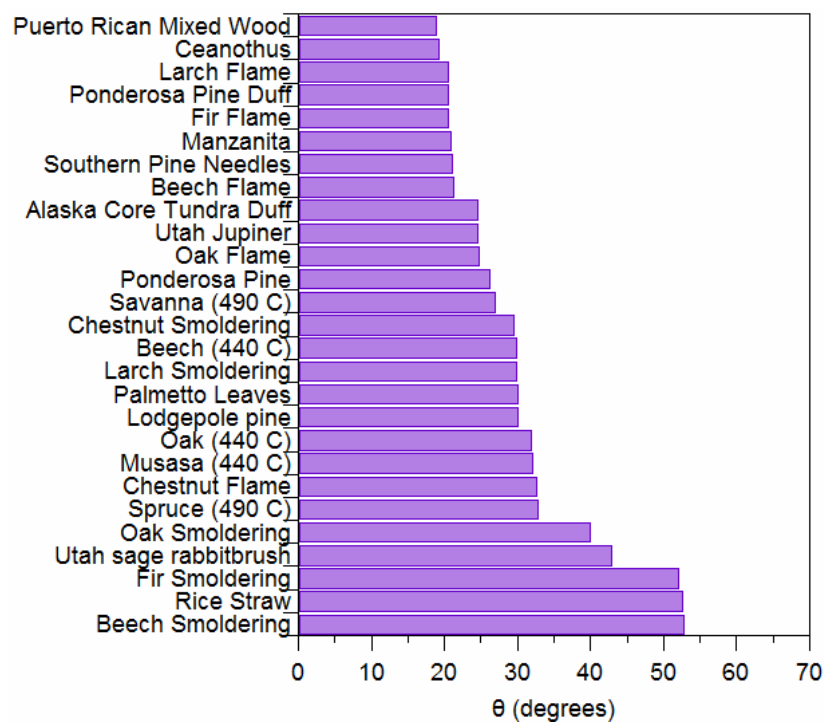

Fig. 3. Angle $\theta$ between the organic mass spectrum of the otBB$\mathrm{OA}$ and various BBOA mass spectra. The otBB-OA mass spectrum is quite different from the rest. (Mass spectra source: http://cires. colorado.edu/jimenez-group/AMSsd/).

The fresh otBB-OA AMS mass spectra in the four experiments were quite similar to each other despite the rather different conditions (concerning the age and the humidity of the branches and the burn of additional mater along with the branches). The angles $\theta$ between the vectors corresponding to the AMS spectra varied from 5 to 13.2 degrees (Table S1). In experiment 4, plastic was burned in addition to the olive tree branches, something that often happens in open olive tree branches fires in the field. Though the inorganic composition was different from the other experiments, e.g., chloride was $21 \%$ and ammonium was detected as well, the organic composition was very similar to experiments 1,2 and 3 .

Figure 3 depicts the angle $\theta$ (Kostenidou et al., 2009) between the organic mass spectra of the otBB-OA and 27 other biomass burning organic aerosol (BBOA) spectra from the AMS mass spectral database (http://cires.colorado.edu/ jimenez-group/AMSsd/). The otBB-OA spectrum was quite different from most of the BBOA mass spectra. Two of the closest spectra were those of Puerto Rican mixed wood and ceanothus with an angle of 19-21 degrees. One of the notable differences between the otBB-OA and other BBOA spectra is the contribution of $m / z 60$, the levoglucosan tracer. Figure 4 shows the contribution of $m / z 60$ in the BBOA mass spectra, with the otBB-OA spectrum having one of the lowest $f_{60}$ fractions. This is consistent with the levoglucosan measurements by GC-MS analysis described above. The fraction $f_{39}$, mostly $\mathrm{C}_{3} \mathrm{H}_{3}^{+}$, of otBB-OA is also lower than in other BBOA spectra (in those that $m / z 39$ has been corrected through the fragmentation table instead of being zero). On the other hand the $f_{37}\left(\mathrm{C}_{3} \mathrm{H}^{+}\right), f_{63}$ (mostly $\left.\mathrm{C}_{5} \mathrm{H}_{3}^{+}\right), f_{67}\left(\mathrm{C}_{3} \mathrm{H}_{7}^{+}\right)$and $f_{91}$

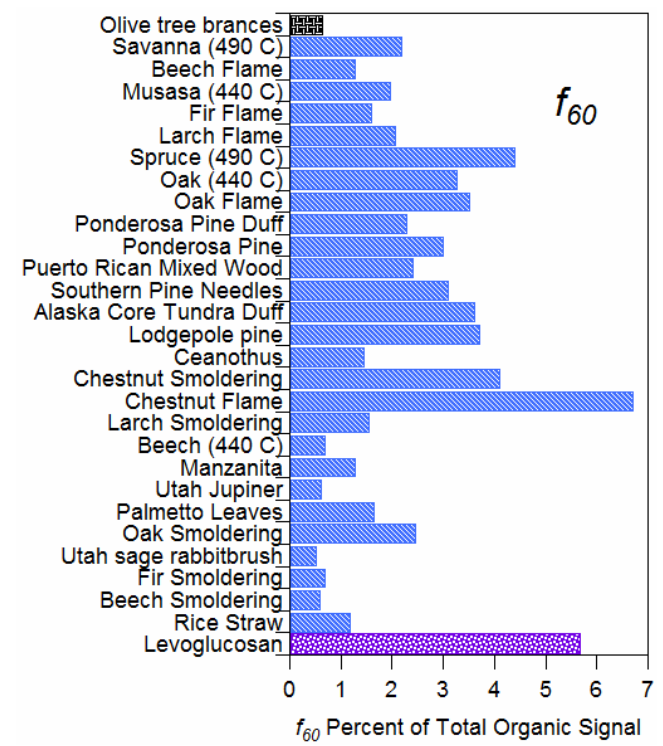

Fig. 4. Contribution of $m / z 60\left(f_{60}\right)$, levoglucosan tracer, to the various BBOA mass spectra. The $f_{60}$ in the olive tree branches burning mass spectrum is only $0.6 \%$.

(mostly $\mathrm{C}_{7} \mathrm{H}_{7}^{+}$) in the otBB-OA spectrum are higher than in most other BBOA (not shown).

\subsection{Chemical aging of otBB-OA}

During the olive tree branches combustion gases such as $\mathrm{O}_{3}$, $\mathrm{NO}, \mathrm{NO}_{2}$ and $\mathrm{CO}$, were also produced. The initial $\mathrm{O}_{3}$ levels in the dark chamber after dilution varied from 45 to $230 \mathrm{ppb}$ (Table 1). There was considerable $\mathrm{NO}_{\mathrm{x}}(30-200 \mathrm{ppb})$ and $\mathrm{CO}$ (3 to $10 \mathrm{ppm}$ ) also present (not shown). OH levels (Table 1) were estimated using the decay of $\mathrm{m} / z 93$ (toluene concentration which was emitted during the burning) in the PTR-MS assuming a second order reaction (Barmet et al., 2012). The $\mathrm{OH}$ concentrations calculated, were $0.4-1.0 \times$ $10^{6}$ molecules $\mathrm{cm}^{-3}$. Thus, there were two oxidants in the chamber $\left(\mathrm{O}_{3}\right.$ and $\left.\mathrm{OH}\right)$ in all experiments.

Figure 5 illustrates the time series of $f_{44}$ and $f_{43}$ during experiment 2 . Time zero denotes the time when dilution ended. The $f_{44}$ increased with time, while the $f_{43}$ decreased and this behavior was observed in all experiments. For experiment 2 the $\mathrm{O}: \mathrm{C}$ at $t=0$ was approximately 0.22 but after 12 hours it increased to 0.39 . These are indications of chemical aging that is taking place due to reactions of the otBB$\mathrm{OA}$ with $\mathrm{OH}$ radicals and ozone. Figure 6 depicts the angle $\theta$ between the initial organic mass spectrum (at $t=0$ ) with the organic mass spectra throughout the experiment for all experiments. The mass spectra changed with the time. For example in experiment 2 the angle between the initial and the final mass spectrum is around 18 degrees. This is the biggest difference probably due to the higher initial ozone and $\mathrm{OH}$ concentration in experiment 2 and the higher degree 
Table 2. Emission factors of particle and gas phase species emitted during olive tree branches burning for $\mathrm{EF}_{\mathrm{CO}_{2}}{ }^{1500-1700 \mathrm{~g} \mathrm{~kg}}{ }^{-1}$. Units are in $\mathrm{g} \mathrm{kg}^{-1}$ except for particle number where the $\mathrm{EF}$ is in number of particles $\mathrm{kg}^{-1}$.

\begin{tabular}{|c|c|c|c|}
\hline \multirow[t]{2}{*}{ Species } & \multicolumn{3}{|c|}{ Emission Factor } \\
\hline & This work & Sinha et al. (2003) & Yokelson et al. (2009) \\
\hline Organics & $2.6-4.4$ & - & 3.25 \\
\hline Sulfate & $0.26-0.44$ & $0.17 \pm 0.18$ & $0.047 \pm 0.024$ \\
\hline Nitrate & $0.20-0.33$ & $0.16 \pm 0.11$ & $0.233 \pm 0.056$ \\
\hline Chloride & $0.03-0.05$ & $0.97 \pm 1.4$ & 0.509 \\
\hline Black Carbon & $0.14-0.16$ & $0.39 \pm 0.19$ & $0.541 \pm 0.163$ \\
\hline NO & $0.19-0.21$ & $3.3 \pm 0.6$ & 1.733 \\
\hline $\mathrm{NO}_{2}$ & $1.24-1.41$ & - & 4.235 \\
\hline $\mathrm{CO}$ & $37.5-42.5$ & $68 \pm 30$ & $80.18 \pm 19.4$ \\
\hline$m / z, 33$ (Methanol) $^{\mathrm{b}}$ & $1.08-1.22$ & $1.2 \pm 0.46$ & $2.59 \pm 1.27$ \\
\hline$m / z 42$ (Acetonitrile) $^{\mathrm{b}}$ & $0.10-0.12$ & - & 0.5 \\
\hline$m / z, 57$ (Acrolein) ${ }^{\mathrm{b}}$ & $0.48-0.54$ & - & 0.096 \\
\hline$m / z 79$ (Benzene) $^{b}$ & $0.17-0.19$ & $0.18 \pm 0.09$ & 0.759 \\
\hline$m / z 93$ (Toluene) ${ }^{\mathrm{b}}$ & $0.17-0.18$ & $0.13 \pm 0.1$ & - \\
\hline$m / z, 107$ (Xylenes) ${ }^{\mathrm{b}}$ & $0.24-0.27$ & - & - \\
\hline Particle number $(10-500 \mathrm{~nm})$ & $(3.3-3.8) \times 10^{15}$ & $(2.0 \pm 1.5) \times 10^{14 \mathrm{a}}$ & - \\
\hline
\end{tabular}

a Sinha et al. (2003) estimated the EF of particles number for particle size $0.1-3 \mu \mathrm{m}$.

b Species used for the PTR-MS calibration at the specific $m / z$.

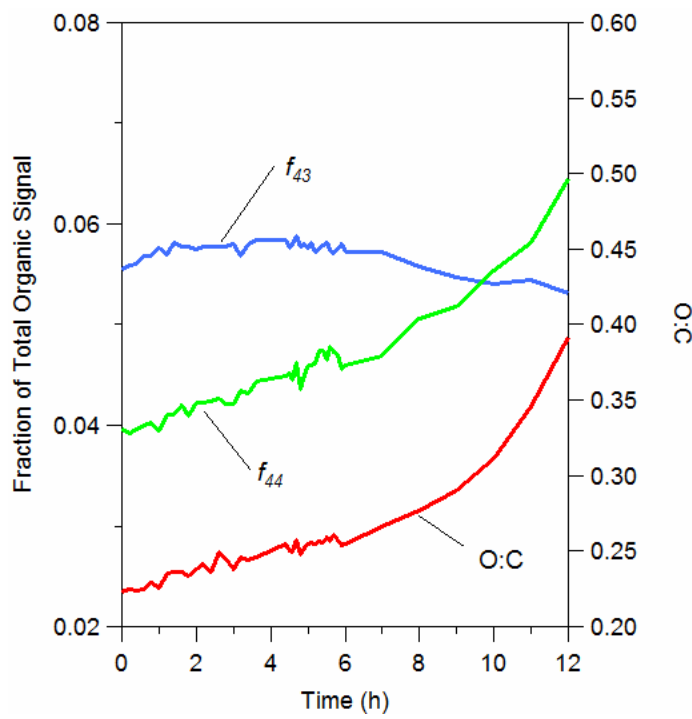

Fig. 5. Time series of $f_{44}, f_{43}$ and $\mathrm{O}: \mathrm{C}$ during the experiment 2. The $f_{44}$ (and $\mathrm{O}: \mathrm{C}$ ) increases throughout the experiment, while the $f_{43}$ decreases, which implies that oxidation takes place. This behavior is characteristic of all experiments.

of aging. Figure S2 compares the HR mass spectra at $t=0$ and $t=11.5 \mathrm{~h}$ for experiment 2 , where the $f_{44}\left(\mathrm{CO}_{2}^{+}\right)$has increased while the hydrocarbon part of the $m / z$ 's $(29,39,41$, $43,55,57,67,69,71$, etc.) has decreased. For all the experiments there was no significant increase of the organic mass (e.g., due to heterogeneous reactions) as the percent decay of

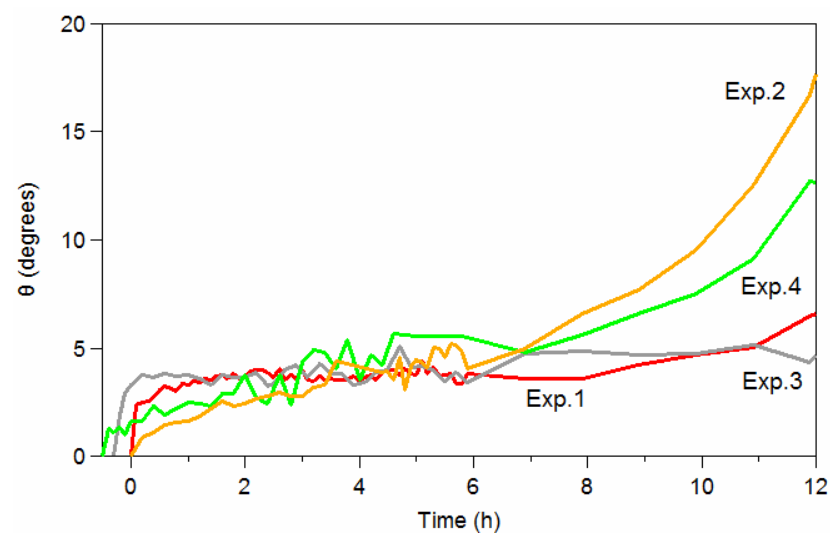

Fig. 6. Angle $\theta$ between the initial organic mass spectrum and the organic mass spectra throughout the whole experiment for the experiments 1-4 versus time. For experiment 2, where the initial ozone concentration is higher, the oxidation is stronger and the angle between the initial and the final mass spectrum is higher in comparison with the other experiments.

the organics was practically equal to the percent decay of the sulfate.

During experiment 2 FTIR filters were collected directly from the fire and from the chamber during the first hour of the experiment. FTIR analysis revealed that the carboxylic acid groups during the first hour in the chamber increased to $12.2 \%$ compared to the carboxylic acid groups directly emitted from the fire $(10.3 \%)$ as shown in Fig. S1. However, carbonyl functional groups did not practically change. 


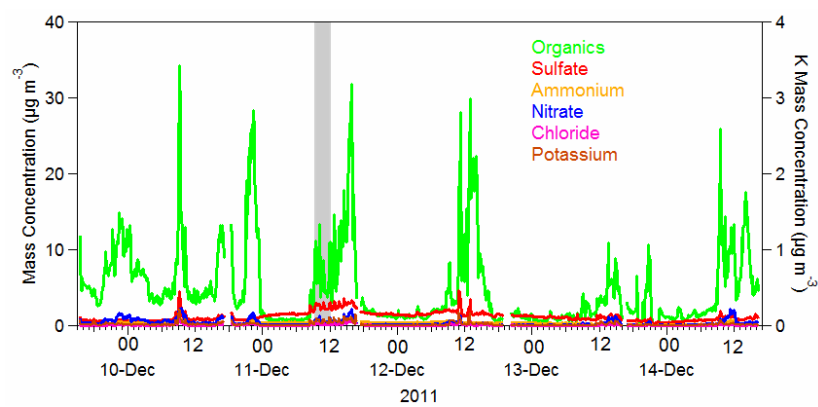

Fig. 7. Example of ambient AMS measurements for 9 to 14 December 2011. Most of the high OA periods are due to olive tree branches burning in the fields around the sampling area. The mass spectrum during 09:00-12:00 LT on 11 December (shaded area) is shown in Fig. 8.

\subsection{Volatile organic compounds}

A number of mass to charge ratios were monitored by the PTR-MS. Due to the limitations present in the identification of the specific VOCs exclusively through PTR-MS (DeGouw et al., 2003), only certain species are reported (Table 2), which have been found to dominate the specific $\mathrm{m} / \mathrm{z}$ during previous biomass burning studies (Christian et al., 2003; DeGouw et al., 2003; Karl et al., 2007). The major compounds detected from olive tree branches burning were methanol $(m / z 33)$, acetonitrile $(m / z 42)$, acrolein $(m / z 57)$, benzene $(\mathrm{m} / \mathrm{z} 79)$, toluene $(\mathrm{m} / \mathrm{z} 93)$ and xylenes $(\mathrm{m} / \mathrm{z} 107)$. However, high signal was observed at additional $\mathrm{m} / \mathrm{z}$ 's, for which either multiple species are reported in the literature at analogous concentrations or there was no standard compound available for calibration. Methanol, benzene, toluene and formaldehyde have been identified in fires in Southern Africa, in Yucatan and in laboratory biomass burning (Christian et al., 2003; Sinha et al., 2003; Yokelson et al., 2003 and 2009). In experiment 2 , where the sample was dominated by the flaming phase the VOC concentrations were 5 to 20 times higher than in experiment 1 , which was a mixture of flaming and smoldering phase. In experiment 2 the branches burned were quite wet, and this resulted in a prolonged ignition phase. Thus the prolonged evaporation of water during this phase could have enhanced the VOC emission from the fuel.

\section{Ambient measurements during the burning season}

\subsection{Chemical composition and mass spectra}

Figure 7 shows the $\mathrm{PM}_{1}$ non-refractory composition measured by the HR-AMS from 9 to 14 December 2011 (5 out of the 20 sampling days). For all the ambient data sets we used an average CE of 0.6. During the burning season (20 days of sampling) the aerosol as measured by the

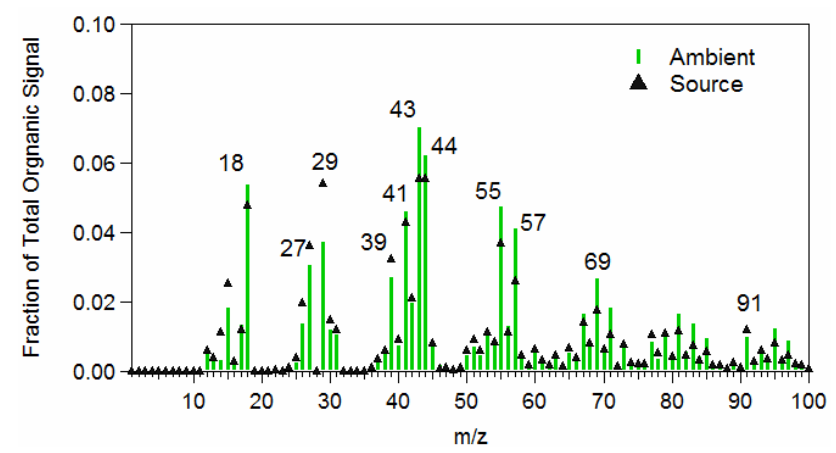

Fig. 8. Comparison between the average mass spectrum from the 4 chamber experiments and the average mass spectrum on 11 December 2012, 09:00-12:00 LT. The angle $\theta$ between the two spectra is equal to 13.6 degrees.

HR-AMS was composed of $58.8 \%$ organics, $30.2 \%$ sulfate, $7.5 \%$ ammonium, $3.2 \%$ nitrate, and $0.7 \%$ chloride. On average the organic mass concentration for the same period was $5.73 \mu \mathrm{g} \mathrm{m}^{-3}$, the sulfate was $2.96 \mu \mathrm{g} \mathrm{m}^{-3}$ and the ammonium was $0.73 \mu \mathrm{g} \mathrm{m}^{-3}$. The average $\mathrm{O}: \mathrm{C}$ ratio was around 0.59 , which is typical for winter in southern Europe. For example the $\mathrm{O}: \mathrm{C}$ ratio during the winter of 2009 at Finokalia, Greece, was 0.54 (Hildebrandt et al., 2011). The average ozone concentration was $36.8 \mathrm{ppb}$ and the average fraction of fragment 44 was 0.12 .

The vast majority of the high organic PM periods were due to olive tree branches burning in the fields around the ICE-HT Institute, reaching a maximum $\mathrm{PM}_{1}$-NR concentration of around $40 \mu \mathrm{g} \mathrm{m}^{-3}$. Chloride for the fire periods correlated with potassium $\left(R^{2}=0.47\right)$ indicating the emission of potassium chloride. The organic mass spectrum during the fire events was very similar to the fresh average spectrum measured in the chamber experiments. Figure 8 shows a comparison of the average mass spectrum from the chamber to the average mass spectrum on 11 December 2012, 09:0012:00 LT ( $\theta=13.6$ degrees) when a fire was observed within a distance of $1 \mathrm{~km}$. The ambient mass spectrum was characterized by the $m / z$ 's $27,29,39,41,43,44,55,57,69$ and 91 .

\subsection{Positive Matrix Factorization}

Multiple PMF solutions were examined and evaluated for both UMR and HR organic mass spectra. A 3-factor PMF solution was found to describe best the ambient OA AMS composition variation. The factors corresponded to otBBOA, HOA and OOA. The correlation coefficient between the UMR spectra and the HR spectra (for the same PMF factor) are $0.92,0.99$ and 0.88 for OOA, HOA and otBB-OA, respectively. Since the HR mass spectra provide more information than the UMR the HR solution is presented here. More details about PMF analysis are provided in Sect. 6 of the Supplement. Figure 9 shows the spectra of the 3 factors, OOA, HOA and otBB-OA and Fig. 10 shows the 3 factor time series 


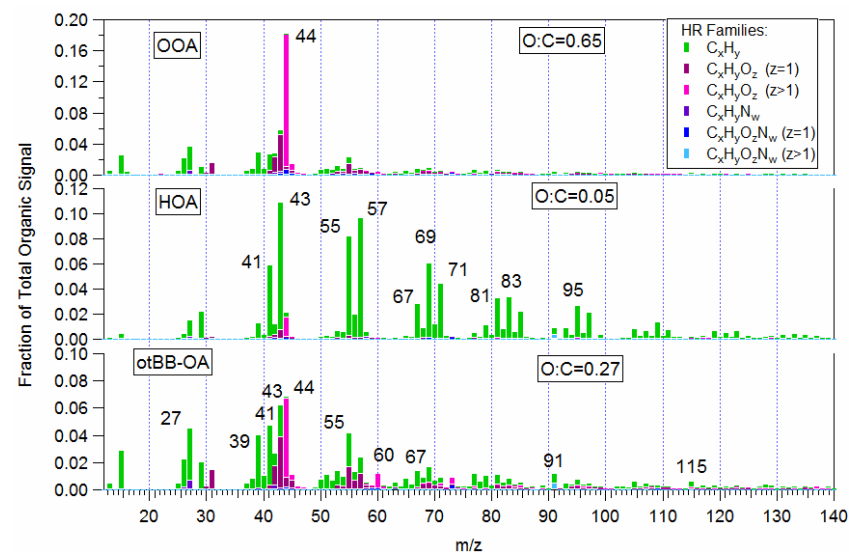

Fig. 9. Mass spectra of OA components from the PMF 3-factor solution.

for the 20 days. On average the organic matter consisted of $55 \%$ OOA, $11.3 \%$ HOA and $33.7 \%$ otBB-OA. This implies that the burning of olive tree branches contributes significantly to the average OA during the burning season. The average otBB-OA organic mass concentration was approximately $1.9 \mathrm{\mu g} \mathrm{m}^{-3}$ for the 20 sampling days, but during the fire events it reached concentrations up to $27 \mu \mathrm{g} \mathrm{m}^{-3}$. During the same period in the center of Patras, approximately $8 \mathrm{~km}$ east, the organic mass concentration was around $20 \mu \mathrm{g} \mathrm{m}^{-3}$ based on filter measurements (Pikridas et al., 2013). This suggests that the impact of these burns extends to tens of kilometers and probably to even larger scales.

The $\mathrm{O}: \mathrm{C}$ ratio of the otBB-OA mass spectrum (PMF) was 0.27 which is consistent with the average chamber $\mathrm{O}: \mathrm{C}$ ratio of the fresh emissions $(0.29 \pm 0.04)$. This value is a little higher than other BBOA sources (e.g., Lanz et al., 2007; Mohr et al., 2012). The HOA mass spectrum is characterized by low $\mathrm{O}: \mathrm{C}$ ratio $(0.05)$ which is in the range of previous studies. For example the HOA factor of Mohr et al. (2012) had an $\mathrm{O}: \mathrm{C}$ ratio around 0.03 , while in the HOA mass spectrum reported by Ulbrich et al. (2009) the $\mathrm{O}: \mathrm{C}$ ratio was 0.18 . The OOA spectrum had the highest $\mathrm{O}: \mathrm{C}$ ratio $(0.65)$, which suggests a high degree of oxidation.

The OOA factor time series correlates very well with sulfate $\left(R^{2}=0.56\right)$, ammonium $\left(R^{2}=0.73\right)$ (Table $\left.\mathrm{S} 2\right)$, which is typical for OOA (e.g., Hildebrandt et al., 2011; Elsasser et al., 2012). The sulfate correlation here is somehow lower than the ammonium probably due to its emission during fire periods as potassium sulfate. Nitrate concentrations were very low during the non-fire periods.

Potassium and chloride correlated well with otBB-OA ( $R^{2}=0.34$ and $R^{2}=0.53$ ) further confirming that potassium chloride is emitted during olive tree branches fires (Pratt et al., 2011). Nitrate also has a good correlation with otBB$\mathrm{OA}\left(R^{2}=0.61\right)$, as potassium nitrate is emitted as well (Pratt et al., 2011). Although the contribution of the levoglucosan markers $\mathrm{C}_{2} \mathrm{H}_{4} \mathrm{O}_{2}^{+}$at $m / z 60$ and $\mathrm{C}_{3} \mathrm{H}_{5} \mathrm{O}_{2}^{+}$at $m / z 73$ is low,
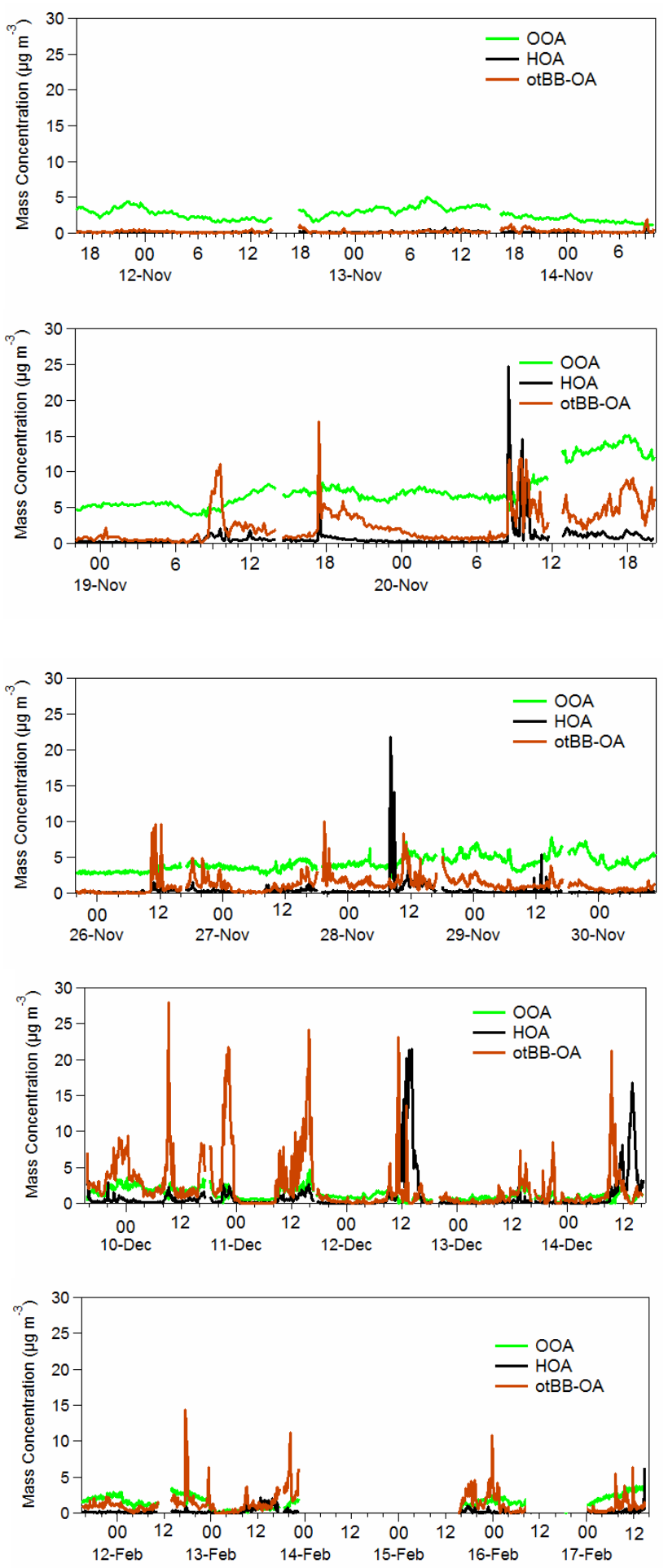

Fig. 10. Time series of the 3 PMF factors for the 20 days, separated in 5 data sets, with an average $\mathrm{CE}=0.6$ applied. The 3 large HOA spikes on 28 November and 12 and 14 December are probably due to the Institute diesel power generator, which was activated during a series of power outages. 
Table 3. Correlations between PMF factors from this work and PMF factors from previous studies.

\begin{tabular}{llc}
\hline OOA & Reference & $\begin{array}{c}\text { Angle } \\
\text { (degrees) }\end{array}$ \\
\hline Pittsburgh & Zhang et al. (2005) & 25.2 \\
Zurich, summer (OOA-LV) & Lanz et al. (2007) & 13.3 \\
Zurich, summer (OOA-SV) & Lanz et al. (2007) & 70.8 \\
Zurich, winter & Lanz et al. (2008) & 20.8 \\
Pittsburgh (OOA-LV) & Ulbrich et al. (2009) & 25.8 \\
Pittsburgh (OOA-SV) & Ulbrich et al. (2009) & 40.8 \\
Barcelona (OOA-LV) & Mohr et al. (2012) & 49.1 \\
Barcelona (OOA-SV) & Mohr et al. (2012) & 52.7 \\
Paris, winter & Crippa et al. (2013) & 33.1 \\
\hline HOA & Reference & Angle \\
& & $($ degrees) \\
\hline Pittsburgh & Zhang et al. (2005) & 14.4 \\
Zurich, summer & Lanz et al. (2007) & 22.0 \\
Zurich, winter & Lanz et al. (2008) & 13.5 \\
Pittsburgh & Ulbrich et al. (2009) & 19.8 \\
Barcelona & Mohr et al. (2012) & 10.8 \\
Paris, winter & Crippa et al. (2013) & 25.6 \\
\hline BBOA & Reference & Angle \\
& & $($ degrees) \\
\hline Zurich, summer & Lanz et al. (2007) & 49.9 \\
Zurich, winter & Lanz et al. (2008) & 38.8 \\
Barcelona & Mohr et al. (2012) & 72.8 \\
Paris, winter & Crippa et al. (2013) & 49.8 \\
FAME-09 & Hildebrandt et al. (2011) & 59.9 \\
Olive tree branches burning & This work & 10.6 \\
\hline & & \\
& &
\end{tabular}

we find that these ions have a good correlation with the otBBOA factor $\left(R^{2}=0.87\right.$ for both, Table S2).

In Table 3 we compare the 3 profiles with selected PMF factors found in the literature (Zhang et al., 2005; Lanz et al., 2007, 2008; Ulbrich et al., 2009; Hildebrandt et al., 2011; Mohr et al., 2012; Crippa et al., 2013). For example the angle $\theta$ between our OOA and the OOA estimated by Lanz et al. (2008) for winter at Zurich is 20.8 while the $\theta$ between our HOA and the HOA found by Mohr et al. (2012) in Barcelona is 10.8 degrees. The $\theta$ between the otBB-OA extracted from this work and the OB-OA factor from FAME09 (Hildebrandt et al., 2011) is quite high. This difference might be due to the very low concentrations at Finokalia during the winter campaign of FAME-09 that may result in noisier mass spectra and/or due to additional biomass burning at Finokalia (e.g., grass). The PMF otBB-OA spectrum and the chamber otBB-OA spectrum are very alike resulting in a $\theta$ of 10.6. This suggests that the ambient otBB-OA that was sampled had undergone relatively little processing and that our source samples are representative of the otBB-OA emitted to the atmosphere.

Figure 11 illustrates the ambient and the chamber OA data in the $\mathrm{Ng}$ triangle ( $\mathrm{Ng}$ et al., 2010). Our ambient winter ICEHT OA falls within the triangle. The chamber otBB-OA and

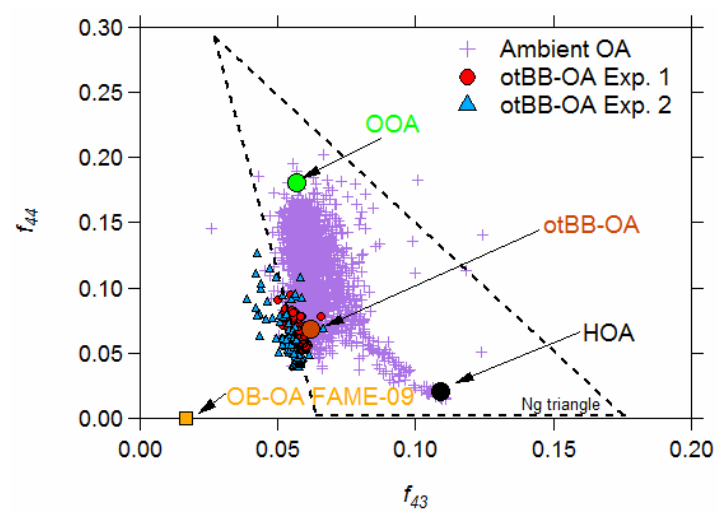

Fig. 11. Ambient and chamber OA data in the Ng et al. (2010) triangle. The ambient OA falls within the triangle. The chamber otBB$\mathrm{OA}$ and the otBB-OA PMF solution are near the bottom left side of the triangle.

the otBB-OA derived by the PMF analysis fall near the bottom left side of the triangle.

\subsection{Size distributions}

Figure 12 shows the size distributions measured during experiment 1 . The vacuum aerodynamic diameter mode for the AMS was around $240 \mathrm{~nm}$ (Fig. 12b). The ambient mass distribution during a fire event, for example on 11 December 2012, 09:00-12:00 LT, had a peak at $300 \mathrm{~nm}$ (not shown). The mass mode diameter was higher in the ambient case because there were also aged, larger particles present together with those from the biomass burning. For the chamber experiments we used the algorithm of Kostenidou et al. (2007) and we estimated an otBB-OA density of $1.25 \pm 0.16 \mathrm{~g} \mathrm{~cm}^{-3}$ for experiments 1, 2 and 3 . For experiment 4 , where plastic was burned along with the olive tree branches, the estimated otBB-OA density was much lower $0.81 \pm 0.06 \mathrm{~g} \mathrm{~cm}^{-3}$.

Figure 13 shows the number distributions for the ambient data set during 25-30 November 2011, as measured by the SMPS, together with the otBB-OA time series PMF factor. The ambient size distributions during the olive tree branches fires had a number mode mobility diameter, around 60$80 \mathrm{~nm}$, smaller than the mode diameter found in the chamber experiments which was around $120 \mathrm{~nm}$ (Fig. 12a). This could not be entirely due to the pump losses during the chamber filling. Using 2 SMPS systems, we calculated the pump losses measuring ambient and laboratory generated (e.g., using an atomizer) particles (Fig. S12). However, reconstructing the chamber size distributions the mode diameter drops on average only $10 \%$, i.e., $110 \mathrm{~nm}$ (Fig. 12a), which is still higher than the mode diameter when olive fires occur in the fields.

One explanation could be the initial high number concentration in the chamber $\left(250000-500000\right.$ particles $\left.\mathrm{cm}^{-3}\right)$ which leads to rapid coagulation. The ambient number 

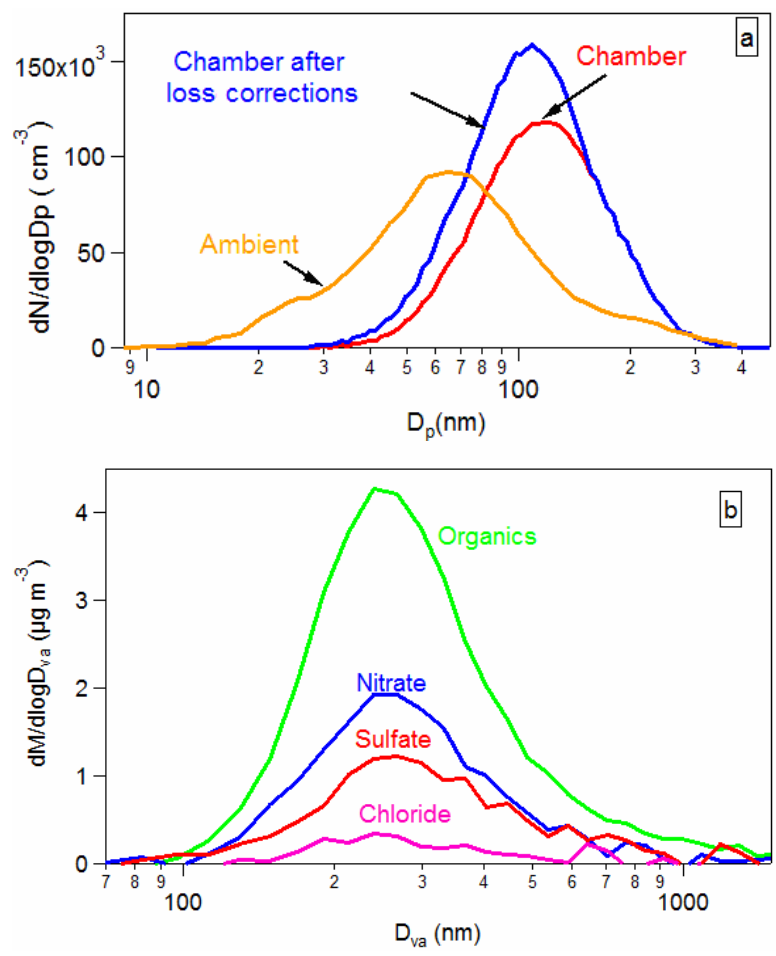

Fig. 12. Size distributions: (a) SMPS distributions from experiment 1 ; the red line is the size distribution as measured in the chamber at $t=0$ (mode diameter $\sim 120 \mathrm{~nm}$ ), the blue line is the reconstructed from the pump losses corrections size distribution for $t=0$ (mode diameter $\sim 109 \mathrm{~nm}$ ) and the orange line is the size distribution during an ambient fire event. (b) AMS mass distributions from experiment 1 (mode diameter $\sim 240 \mathrm{~nm}$ ).

concentrations were less than 60000 particles $\mathrm{cm}^{-3}$. To investigate this we used the TOMAS (Two-Moment Sectional Algorithm, Adams and Seinfeld, 2002) model using as initial condition the ambient otBB-OA size distributions scaled to 500000 particles $\mathrm{cm}^{-3}$ and simulated only coagulation. The simulation showed that the otBB-OA particles coagulated fast and within $1-2 \mathrm{~h}$ reached a mode diameter of $115 \mathrm{~nm}$ (Fig. S13). The duration between the filling of the chamber and the end of the dilution was approximately $1.5 \mathrm{~h}$. Therefore, the growth of the particles in our chamber can be explained by coagulation of the fresh particles. The ambient distribution (mode at $70 \mathrm{~nm}, \sigma=0.4$ ) is the appropriate one for the fresh emissions by this source.

It is worth mentioning that there was no nucleation observed in any of the 4 experiments, however, without adding any oxidants or using UV lamps. Hennigan et al. (2012) observed new particle formation within 30-60 min after initiating photo-oxidation (using UV lamps) on biomass burning emissions.

\subsection{Particle and vapor emissions}

The emission factor $\mathrm{EF}_{i}$ of the species $i$ emitted during the open olive tree branches fires was estimated by

$\mathrm{EF}_{i}=\left[\frac{\left(C_{i}\right)_{\mathrm{p}}-\left(C_{i}\right)_{\mathrm{b}}}{\left(\mathrm{CO}_{2}\right)_{\mathrm{p}}-\left(\mathrm{CO}_{2}\right)_{\mathrm{b}}}\right] \mathrm{EF}_{\mathrm{CO}_{2}}$

where $\left(C_{i}\right)_{\mathrm{p}}$ and $\left(\mathrm{CO}_{2}\right)_{\mathrm{p}}$ are the species $i$ and $\mathrm{CO}_{2}$ concentrations in the plume, $\left(C_{i}\right)_{\mathrm{b}}$ and $\left(\mathrm{CO}_{2}\right)_{\mathrm{b}}$ are the corresponding concentrations in the background, i.e., the average level before and after the fire plume and $\mathrm{EF}_{\mathrm{CO}_{2}}$ is the emission factor of $\mathrm{CO}_{2}$, that is the mass of $\mathrm{CO}_{2}$ emitted per mass of olive tree branches burned. The $\mathrm{EF}_{\mathrm{CO}_{2}}$ is $1600 \pm 100 \mathrm{~g} \mathrm{~kg}^{-1}$ for various types of woods (e.g., Kaufmann et al., 1992; Andeae and Merlet, 2001; Christian et al., 2003; Yokelson et al., 2003, 2009). The olive tree branches burning plumes were indentified using the otBB-OA PMF factor.

On average the EF for the otBB-OA was estimated to be $3.5 \pm 0.9 \mathrm{~g} \mathrm{~kg}^{-1}$ (Table 2), which is lower than the EF calculated from Darley et al. (1974). According to this estimate up to 4600 tons of fine organic aerosol will be produced during the winter months in Greece if all pruned olive branches are burned, which is quite high compared for example to the annual emissions of the passenger cars (150 tons per year). Assuming a low $\mathrm{EF}_{\mathrm{CO}_{2}}$ of $1000 \mathrm{~g} \mathrm{~kg}^{-1}$ the otBB-OA EF would be $2.1 \pm 0.6 \mathrm{~g} \mathrm{~kg}^{-1}$ and the emitted otBB-OA will be around 2800 tons, which is still a significant amount.

The nitrate EF was in the range $0.20-0.33 \mathrm{~g} \mathrm{~kg}^{-1}$, which is consistent with the measurements of Sihna et al. (2003) and Yokelson et al. (2009) for savanna fires in Africa and tropical forests in Yucatan. The sulfate EF was in the range $0.26-0.44 \mathrm{~g} \mathrm{~kg}^{-1}$, higher than other sulfate EFs (Table 2), while the BC EF was $0.15 \mathrm{~g} \mathrm{~kg}^{-1}$, lower than published values. For particles in the range $10-500 \mathrm{~nm}$ the EF was equal to $3.5 \pm 0.35 \times 10^{15}$ particles $\mathrm{kg}^{-1}$. This is higher than the EF reported by Sihna et al. (2003) $2.0 \pm 1.5 \times 10^{14}$ particles $\mathrm{kg}^{-1}$, probably because their EF was estimated for larger particles $(0.1-3 \mu \mathrm{m})$. The EF of $\mathrm{CO}$ is lower than in other studies, $40 \pm 2.5 \mathrm{~g} \mathrm{~kg}^{-1}$, while the benzene and toluene EFs are quite close to the EFs calculated by Sihna et al. (2003). Methanol and acetonitrile EFs are lower than the values published by Yokelson et al. (2009). These are summarized in Table 2.

\section{Conclusions}

We conducted source characterization and ambient experiments in order to describe and estimate the olive tree branches burning emissions. In addition to $\mathrm{NO}_{\mathrm{x}}, \mathrm{O}_{3}, \mathrm{CO}$ and $\mathrm{CO}_{2}$, VOCs such as methanol, acetonitrile, acrolein, benzene, toluene and xylenes were also detected. The size distributions of the fresh olive tree branches fires had a number mode mobility diameter of $60-80 \mathrm{~nm}$. The aerosol emitted consists of organics, BC, potassium, chloride, nitrate and sulfate. FTIR functional group analysis showed that otBB-OA 


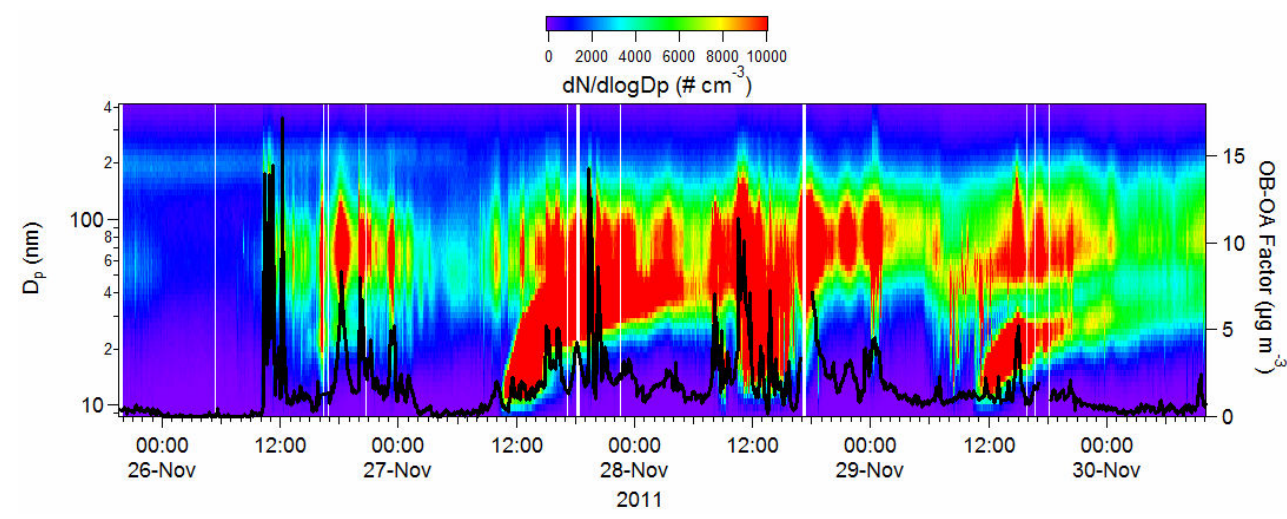

Fig. 13. Size distributions (left axis) plotted with the otBB-OA factor (black solid line, right axis) versus the time from the data set 26 to 30 November. When the otBB-OA contribution increases the particle diameter is around 60-70 $\mathrm{nm}$.

was composed of $49 \%$ alkane groups, $28 \%$ organic hydroxyl groups, $10 \%$ carboxylic acid groups, $10 \%$ primary amine groups and $3 \%$ carbonyl groups, with fractions calculated by organic mass rather than moles. The $\mathrm{O}: \mathrm{C}$ ratio of the fresh otBB-OA was estimated $0.29 \pm 0.04$. The AMS mass spectrum of otBB-OA is characterized by the $m / z$ 's $27,29,39$, $41,43,44,55,57,67,69$ and 91 . This mass spectrum is quite different from other biomass burning OA mass spectra. After $12 \mathrm{~h}$ of exposure to approximately $10^{6}$ molecules $\mathrm{cm}^{-3}$ of $\mathrm{OH}$ and $200 \mathrm{ppb} \mathrm{O}_{3}$, the otBB-OA mass spectrum changes significantly $(\theta=18$ degrees) with the $\mathrm{O}: \mathrm{C}$ increasing to 0.39. Part of this change is due to the production of acids.

The levoglucosan to $\mathrm{PM}_{1}$ OC ratio was low (0.034-0.043) compared to most biomass burning sources. This may lead to an underestimation of the biomass burning in Southern Europe, where burning of olive tree branches is a common agricultural waste management technique in the Mediterranean during the winter and levoglucosan has being used as a wood burning tracer. Applying PMF to ambient AMS measurements, we found 3 factors among them the otBBOA factor contributing $33.7 \%$ to the average organic ambient aerosol. Its mass spectrum is very close to the fresh otBB-OA chamber spectrum. The otBB-OA estimated EF is $3.5 \pm 0.9 \mathrm{~g} \mathrm{~kg}^{-1}$ and it is an important source in the Greek and the Mediterranean area during the winter months. These emissions should be included in emission inventories and corresponding CTMs.

\section{Supplementary material related to this article is available online at http://www.atmos-chem-phys.net/13/ 8797/2013/acp-13-8797-2013-supplement.pdf.}

Acknowledgements. We thank David Patoulias for his assistance with the TOMAS model and Albert Presto for his help with the pump losses. This research was supported by the European
Research Council Project ATMOPACS (Atmospheric Organic Particulate Matter, Air Quality and Climate Change Studies) (Grant Agreement 267099). L. M. Russell acknowledges support from NSF ATM-0904203 for FTIR analyses.

Edited by: A. Nenes

\section{References}

Abas, M. R., Simoneit, B. R. T., Elias, V., Cabral, J. A., and Cardoso, J. N.: Composition of higher molecular weight organic matter in smoke aerosol from biomass combustion in Amazonia, Chemosphere, 30, 995-1015, 1995.

Adams, P. J. and Seinfeld, J. H.: Predicting global aerosol size distributions in general circulation models, J. Geophys. Res., 107, 4370, doi:10.1029/2001JD001010, 2002.

Aiken, A. C., DeCarlo, P. F., Kroll, J. H., Worsnop, D. R., Huffman, J. A., Docherty, K., Ulbrich, I. M., Mohr, C., Kimmel, J. R., Sueper, D., Sun, Y., Zhang, Q., Trimborn, A. M., Northway, M. J., Ziemann, P. J., Canagaratna, M. R., Alfarra, M. R., Prevot, A. S. H., Dommen, J., Duplissy, J., Metzger, A., Baltensperger, U., and Jimenez, J. L.: O/C and OM/OC ratios of primary, secondary, and ambient organic aerosols with high resolution timeof-flight aerosol mass spectrometry, Environ. Sci. Technol., 42, 4478-4485, 2008.

Alfarra, M. R., Prevot, A. S. H., Szidat, S., Sandradewi, J., Weimer, S., Lanz, V., Schreiber, D., Mohr, M., and Baltensperger, U.: Identification of the mass spectral signature of organic aerosols from wood burning emissions, Environ. Sci. Technol., 41, 57705777, 2007.

Andreae, M. O.: Climatic effects of changing atmospheric aerosol levels, in: World Survey of Climatology. Vol. 16: Future climates of the world, edited by: Henderson-Sellers, A., Elsevier, Amsterdam, 341-392, 1995.

Andreae, M. O. and Merlet, P.: Emission of trace gases and aerosols form biomass burning, Global Biochem. Cy., 15, 955-966, 2001.

Barmet, P., Dommen, J., DeCarlo, P. F., Tritscher, T., Praplan, A. P., Platt, S. M., Prévôt, A. S. H., Donahue, N. M., and Baltensperger, U.: $\mathrm{OH}$ clock determination by proton transfer reaction mass spectrometry at an environmental chamber, Atmos. Meas. Tech., 
5, 647-656, doi:10.5194/amt-5-647-2012, 2012.

Boman, B. C., Forsberg, A. B., and Järvholm, B. G.: Adverse health effects from ambient air pollution in relation to residential wood combustion in modern society, Scand. J. Work Env. Hea., 29, 251-260, 2003.

Capes, G., Johnson, B., McFiggans, G., Williams, P. I., Haywood, J., and Coe, H.: Aging of biomass burning aerosols over West Africa: Aircraft measurements of chemical composition, microphysical properties, and emission ratios, J. Geophys. Res., 113, D00C15, doi:10.1029/2008JD009845, 2008.

Christian, T. J., Kleiss, B., Yokelson, R. J., Holzinger, R., Crutzen, P. J., Hao, W. M., Saharjo, B. H., and Ward D. E.: Comprehensive laboratory measurements of biomass burning emissions: 1 . Emissions from Indonesian, African, and other fuels, J. Geophys. Res., 108, 4719, doi:10.1029/2003JD003704, 2003.

Crippa, M., DeCarlo, P. F., Slowik, J. G., Mohr, C., Heringa, M. F., Chirico, R., Poulain, L., Freutel, F., Sciare, J., Cozic, J., Di Marco, C. F., Elsasser, M., Nicolas, J. B., Marchand, N., Abidi, E., Wiedensohler, A., Drewnick, F., Schneider, J., Borrmann, S., Nemitz, E., Zimmermann, R., Jaffrezo, J.-L., Prévôt, A. S. $\mathrm{H}$., and Baltensperger, U.: Wintertime aerosol chemical composition and source apportionment of the organic fraction in the metropolitan area of Paris, Atmos. Chem. Phys., 13, 961-981, doi:10.5194/acp-13-961-2013, 2013.

Crounse, J. D., DeCarlo, P. F., Blake, D. R., Emmons, L. K., Campos, T. L., Apel, E. C., Clarke, A. D., Weinheimer, A. J., McCabe, D. C., Yokelson, R. J., Jimenez, J. L., and Wennberg, P. O.: Biomass burning and urban air pollution over the Central Mexican Plateau, Atmos. Chem. Phys., 9, 4929-4944, doi:10.5194/acp-9-4929-2009, 2009.

Crutzen, P. J. and Andreae, M. O.: Biomass burning in the tropics: Impact on atmospheric chemistry and biogeochemical cycles, Science, 250, 1669-1678, 1990.

Darley, E. F., Miller Jr., G. E., Goss, J. R., and Biswell, H. H.: Air pollution from forest and agricultural burning. California Air Resources Board Project 2-017-1, California Air Resources Board Project No. 2-017-1, University of California, Davis, CA, April 1974.

DeCarlo, P. F., Kimmel, J. R., Trimborn, A., Northway, M. J., Jayne, J. T., Aiken, A. C., Gonin, M., Fuhrer, K., Horvath, T., Docherty, K., Worsnop, D. R., and Jimenez, J. L.: Fielddeployable, high-resolution, time-of-flight aerosol mass spectrometer, Anal. Chem., 78, 8281-8289, 2006.

DeGouw, J., Warneke, C., Karl, T., Eerdekens, G., Van Der Veen, C., and Fall, R.: Sensitivity and specificity of atmospheric trace gas detection by proton-transfer-reaction mass spectrometry, Int. J. Mass Spectrom., 223-224 365-382, 2003.

Elsasser, M., Crippa, M., Orasche, J., DeCarlo, P. F., Oster, M., Pitz, M., Gustafson, T. L., Pettersson, J. B. C., Schnelle-Kreis, J., Prévôt, A. S. H., and Zimmermann, R.: Organic molecular markers and signature from wood combustion particles in winter ambient aerosols: aerosol mass spectrometer (AMS) and high timeresolved GC-MS measurements in Augsburg, Germany, Atmos. Chem. Phys., 12, 6113-6128, doi:10.5194/acp-12-6113-2012, 2012.

EPA: Emission facts: Average annual emissions and fuel consumption for gasoline-fueled passenger cars and light tracks, EPA420F-05-022, 2005.
Fang, M., Zheng, M.,Wang, F., To, K. L., Jaafar, A. B., and Tong, S. L.: The solvent-extractable organic compounds in the Indonesia biomass burning aerosols-characterization studies, Atmos. Environ., 33, 783-795, 1999.

Fine, P. M., Cass, G. R., and Simoneit, B. R. T.: Chemical characterization of fine particle emissions in the fireplace combustion of woods grown in the Southern United States, Environ. Sci. Technol., 36, 1442-1451, 2002.

Fine, P. M., Cass, G. R., and Simoneit, B. R. T.: Chemical characterization of fine particle emissions from the fireplace combustion of wood types grown in the Midwestern and Western United States, Environ. Eng. Sci., 21, 387-407, 2004.

Gilardoni, S., Russell, L. M., Sorooshian, A., Flagan, R. C., Seinfeld, J. H., Bates, T. S., Quinn, P. K., Allan, J. D., Williams, B., Goldstein, A. H., Onasch, T. B., and Worsnop, D. R.: Regional variation of organic functional groups in aerosol particles on four U.S. east coast platforms during the international consortium for atmospheric research on transport and transformation 2004 campaign, J. Geophys. Res., 112, D10S27, doi:10.1029/2006JD007737, 2007.

Graham, B., Mayol-Bracero, O. L., Guyon, P., Roberts, G. C., Decesari, S., Facchini, M. C., Artaxo, P., Maenhaut, W., Köll, P., and Andreae M. O.: Water-soluble organic compounds in biomass burning aerosols over Amazonia 1. Characterization by NMR and GC-MS, J. Geophys. Res, 107, D20, doi:10.1029/2001JD000336, 2002.

Hawkins, L. N. and Russell L. M.: Oxidation of ketone groups in transported biomass burning aerosol from the 2008 Northern California lightning series fires, Atmos. Environ., 44, 41424154, 2010.

Hennigan, C. H., Sullivan, A. S., Collett Jr., J. L., and Robinson, A. L.: Levoglucosan stability in biomass burning particles exposed to hydroxyl radicals, Geophys. Res. Lett., 37, L09806, doi:10.1029/2010GL043088, 2010.

Hennigan, C. J., Westervelt, D. M., Riipinen, I., Engelhart, G. J., Lee, T., Collett Jr., J. L., Pandis, S. N., Adams, P. J., and Robinson, A. L.: New particle formation and growth in biomass burning plumes: An important source of cloud condensation nuclei, Geophys. Res. Lett., 39, L09805, doi:10.1029/2012GL050930, 2012.

Hildebrandt, L., Kostenidou, E., Lanz, V. A., Prevot, A. S. H., Baltensperger, U., Mihalopoulos, N., Laaksonen, A., Donahue, N. M., and Pandis, S. N.: Sources and atmospheric processing of organic aerosol in the Mediterranean: insights from aerosol mass spectrometer factor analysis, Atmos. Chem. Phys., 11, 1249912515, doi:10.5194/acp-11-12499-2011, 2011.

Hudson, P. K., Murphy, D. M., Cziczo, D. J., Thomson, D. S., de Gouw, J. A., Warneke, C., Holloway, J., Jost, J. R., and Hubler, G.: Biomass-burning particle measurements: Characteristic composition and chemical processing, J. Geophys. Res., 109, D23S27, doi:10.1029/2003JD004398, 2004.

Huffman, J. A., Jayne, J. T., Drewnick, F., Aiken, A. C., Onasch, T., Worsnop, D. R., and Jimenez, J. L.: Design, modeling, optimization, and experimental tests of a particle beam width probe for the aerodyne aerosol mass spectrometer, Aerosol Sci. Technol., 39, 1143-1163, 2005.

Karl, T. G., Christian, T. J., Yokelson, R. J., Artaxo, P., Hao, W. M., and Guenther, A.: The Tropical Forest and Fire Emissions Experiment: method evaluation of volatile organic compound 
emissions measured by PTR-MS, FTIR, and GC from tropical biomass burning, Atmos. Chem. Phys., 7, 5883-5897, doi:10.5194/acp-7-5883-2007, 2007.

Kaufman, Y. J., Setzer, A., Ward, D., Tanre, D., Holben, B. N., Menzel, P., Pereira, M. C., and Rasmussen, R.: Biomass burning airborne and space borne experiment in the Amazonas (BASE - A), J. Geophys. Res., 97, 14581-14599, 1992.

Kostenidou, E., Pathak, R. K., and Pandis, S. N.: An algorithm for the calculation of secondary organic aerosol density combining AMS and SMPS data, Aerosol Sci. Technol., 41, 1002-1010, 2007.

Kostenidou, E., Lee, B. H., Engelhart, G. J., Pierce, J. R., and Pandis, S. N.: Mass spectra deconvolution of low, medium and high volatility biogenic secondary organic aerosol, Environ. Sci. Technol., 43, 4884-4889, 2009.

Lanz, V. A., Alfarra, M. R., Baltensperger, U., Buchmann, B., Hueglin, C., and Prévôt, A. S. H.: Source apportionment of submicron organic aerosols at an urban site by factor analytical modelling of aerosol mass spectra, Atmos. Chem. Phys., 7, 15031522, doi:10.5194/acp-7-1503-2007, 2007.

Lanz, V. A., Alfarra, M. R., Baltensperger, U., Buchmann, B., Hueglin, C., Szidat, S., Wehrli, M. N., Wacker, L., Weimer, S., Caseiro, A., Puxbaum, J., and Prevot, A. S. H.: Source attribution of submicron organic aerosols during wintertime inversions by advanced factor analysis of aerosol mass spectra, Environ. Sci. Technol., 42, 214-220, 2008.

Lighty, J. S., Veranth, J. M., and Sarofim, A. F.: Combustion aerosols: Factors governing their size and composition and implications to human health, J. Air Waste Manage., 50, 1565-1618, 2000.

Liu, S., Takahama, S., Russell, L. M., Gilardoni, S., and Baumgardner, D.: Oxygenated organic functional groups and their sources in single and submicron organic particles in MILAGRO 2006 campaign, Atmos. Chem. Phys., 9, 6849-6863, doi:10.5194/acp9-6849-2009, 2009.

Liu, S., Ahlm, L., Day, D. A., Russell, L. M., Zhao, Y., Gentner, D. R., Weber, R. J., Goldstein, A. H., Jaoui, M., Offenberg, J. H., Kleindienst, T. E., Rubitschun, C., Surratt, J. D., Sheesley, R. J., and Scheller, S.: Secondary organic aerosol formation from fossil fuel sources contribute majority of summertime organic mass at Bakersfield, J. Geophys. Res., 117, D00V26, doi:10.1029/2012JD018170, 2012.

Lobert, J. M., Scharffe, D. H., Hao, W. M., and Crutzen, P. J.: Importance of biomass burning in the atmospheric budgets of nitrogencontaining gases, Nature, 346, 6284, 552-554, 1990.

Maria, S. F., Russell, L. M., Turpin, B. J., and Porcja, R. J.: FTIR measurements of functional groups and organic mass in aerosol samples over the Caribbean, Atmos. Environ., 36, 5185-5196, 2002.

Maria, S. F., Russell, L. M., Turpin, B. J., Porcja, R. J., Campos, T. L., Weber, R. J., and Huebert, B. J.: Source signatures of carbon monoxide and organic functional groups in asian pacific regional aerosol characterization experiment (ACEAsia) submicron aerosol types, J. Geophys. Res, 108, 8637, doi:10.1029/2003JD003703, 2003.

Mohr, C., DeCarlo, P. F., Heringa, M. F., Chirico, R., Slowik, J. G., Richter, R., Reche, C., Alastuey, A., Querol, X., Seco, R., Peñuelas, J., Jiménez, J. L., Crippa, M., Zimmermann, R., Baltensperger, U., and Prévôt, A. S. H.: Identification and quan- tification of organic aerosol from cooking and other sources in Barcelona using aerosol mass spectrometer data, Atmos. Chem. Phys., 12, 1649-1665, doi:10.5194/acp-12-1649-2012, 2012.

Naeher, L. P., Brauer, M., Lipsett, M., Zelikoff, J. T., Simpson, C. D., Koenig, J. Q., and Smith, K. R.: Woodsmoke health effects: A review, Inhal. Toxicol., 19, 67-106, 2007.

Ng, N. L., Canagaratna, M. R., Zhang, Q., Jimenez, J. L., Tian, J., Ulbrich, I. M., Kroll, J. H., Docherty, K. S., Chhabra, P. S., Bahreini, R., Murphy, S. M., Seinfeld, J. H., Hildebrandt, L., Donahue, N. M., DeCarlo, P. F., Lanz, V. A., Prévôt, A. S. H., Dinar, E., Rudich, Y., and Worsnop, D. R.: Organic aerosol components observed in Northern Hemispheric datasets from Aerosol Mass Spectrometry, Atmos. Chem. Phys., 10, 46254641, doi:10.5194/acp-10-4625-2010, 2010.

Paatero, P. and Tapper, U.: Positive matrix factorization - a nonnegative factor model with optimal utilization of error-estimates of data values, Environmetrics, 5, 111-126, 1994.

Petzold, A. and Schönlinner, M: Multi-angle absorption photometry - a new method for the measurement of aerosol light absorption and atmospheric black carbon, J. Aerosol Sci., 35, 421-441, 2004.

Pikridas, M., Tasoglou, A., Florou, K., and Pandis, S. N.: Characterization of the origin of fine particulate matter in a medium size urban area in the Mediterranean, Atmos. Environ., 80, 264-274, 2013.

Pratt, K. A., Murphy, S. M., Subramanian, R., DeMott, P. J., Kok, G. L., Campos, T., Rogers, D. C., Prenni, A. J., Heymsfield, A. J., Seinfeld, J. H., and Prather, K. A.: Flight-based chemical characterization of biomass burning aerosols within two prescribed burn smoke plumes, Atmos. Chem. Phys., 11, 1254912565, doi:10.5194/acp-11-12549-2011, 2011.

Puxbaum, H., Caseiro, A., Sanchez-Ochoa, A., Kasper-Giebl, A., Claeys, M., Gelencser, A., Legrand, M., Preunkert, S., and Pio, C.: Levoglucosan levels at background sites in Europe for assessing the impact of biomass combustion on the aerosol European background, J. Geophys. Res., 112, D23S05, doi:10.1029/2006JD008114, 2007.

Reid, J. S., Koppmann, R., Eck, T. F., and Eleuterio, D. P.: A review of biomass burning emissions part II: intensive physical properties of biomass burning particles, Atmos. Chem. Phys., 5, 799825, doi:10.5194/acp-5-799-2005, 2005.

Roberts, G. C., Artaxo, Zhou, P. J., Swietlicki, E., and Andreae, M. O.: Sensitivity of CCN spectra on chemical and physical properties of aerosol: A case study from the Amazon Basin, J. Geophys. Res., 107, 8070, doi:10.1029/2001JD000583, 2002.

Rogers, C. F., Hudson, J. G., Zielinska, B., Tanner, R. L., Hallett, J., and Watson, J. G.: Cloud condensation nuclei from biomass burning, in: Global biomass burning, proceedings of the Chapman conference on global biomass burning: Atmospheric, climatic, and biospheric implications, edited by: Levine, J. S., MIT Press, Cambridge, Mass., 431-438, 1991.

Russell, L. M., Takahama, S., Liu, S., Hawkins, L. N., Covert, D. S., Quinn, P. K., and Bates, T. S.: Oxygenated fraction and mass of organic aerosol from direct emission and atmospheric processing measured on the R/V Ronald Brown during TEXAQS/GoMACCS 2006, J. Geophys. Res.-Atmos., 114, D00F05, doi:10.1029/2008JD011275, 2009.

Schneider, J., Weimer, S., Drewnick, F., Borrmann, S., Helas, G., Gwaze, P., Schmid, O., Andreae, O., and Kirchner, U.: Mass 
spectrometric analysis and aerodynamic properties of various types of combustion-related aerosol particles, Int. J. Mass Spectrom., 258, 37-49, 2006.

Schüle, W.: Landscapes and climate in prehistory: Interactions of wildlife, man and fire, in: Fire in the tropical biota: Ecosystem processes and global challenges, edited by: Goldammer, J., Springer-Verlag, New York, 273-318, 1990.

Shafizadeh, F.: The chemistry of pyrolysis and combustion, in: Chemistry of solid wood, edited by: Rowell, R., Adv. Chem. Series 207, American Chemical Society, Washington, DC, 489$529,1984$.

Shafizadeh, F. and Fu, Y. L.: Pyrolysis of cellulose, Carbohyd. Res., 29, 113-122, 1973.

Shafizadeh, F., Furneaux, R. H., Cochran, T. G., Scholl, J. P., and Sakai, Y.: Production of levoglucosan and glucose from pyrolysis of cellulosic materials, J. Appl. Polym. Sci., 23, 3525-3539, 1979.

Simoneit, B. R. T., Schauer, J. J., Nolte, C. G., Oros, D. R., Elias, V. O., Fraser, M. P., Rogge, W. F., and Cass, G. R.: Levoglucosan, a tracer for cellulose in biomass burning and atmospheric particles, Atmos. Environ., 33, 173-182, 1999.

Simpson, C. D., Dills, R. L., Katz, B. S., and Kalman, D. A.: Determination of levoglucosan in atmospheric fine particulate matter, J. Air Waste Manage., 54, 689-694, 2004.

Sinha, P., Hobbs, P. V., Yokelson, R. J., Bertschi, I. T., Blake, D. R., Simpson, I. S., Gao, S., Kirchstetter, T. W., and Novakov, T.: Emissions of trace gases and particles from savanna fires in southern Africa, J. Geophys. Res., 108, 8487, doi:10.1029/2002JD002325, 2003.

Sueper, D.: ToF-AMS high resolution analysis software - Pika, available at: http://cires.colorado.edu/jimenez-group/, ToFAMSResources/ToFSoftware, 2011.

Sullivan, A. P., Holden, A. S., Patterson, L. A., McMeeking, G. R., Kreidenweis, S. M., Malm, W. C., Hao, W. M., Wold, C. E., and Collett Jr., J. L.: A method for smoke marker measurements and its potential application for determining the contribution of biomass burning from wildfires and prescribed fires to ambient $\mathrm{PM}_{2.5}$ organic carbon, J. Geophys. Res., 113, D22302, doi:10.1029/2008JD010216, 2008.
Ulbrich, I. M., Canagaratna, M. R., Zhang, Q., Worsnop, D. R., and Jimenez, J. L.: Interpretation of organic components from Positive Matrix Factorization of aerosol mass spectrometric data, Atmos. Chem. Phys., 9, 2891-2918, doi:10.5194/acp-9-2891-2009, 2009.

Weimer, S., Alfarra, M. R., Schreiber, D., Mohr, M., Prevot, A. S. H., and Baltensperger, U.: Organic aerosol mass spectral signatures from wood-burning emissions: Influence of burning conditions and wood type, J. Geophys. Res., 113, D10304, doi:10.1029/2007JD009309, 2008.

Yamasoe, M. A., Artaxo, P., Miguel, A. H., and Allen, A. G.: Chemical composition of aerosol particles from direct emissions of vegetation fires in the Amazon Basin: Water-soluble species and trace elements, Atmos. Environ., 34, 1641-1653, 2000.

Yokelson, R. J., Bertschi, I. T., Christian, J. T., Hobbs, P. V., Ward, D. E., and Hao, W. M.: Trace gas measurements in nascent, aged, and cloud-processed smoke from African savanna fires by airborne Fourier transform infrared spectroscopy (AFTIR), J. Geophys. Res., 108, 8478, doi:10.1029/2002JD002322, 2003.

Yokelson, R. J., Crounse, J. D., DeCarlo, P. F., Karl, T., Urbanski, S., Atlas, E., Campos, T., Shinozuka, Y., Kapustin, V., Clarke, A. D., Weinheimer, A., Knapp, D. J., Montzka, D. D., Holloway, J., Weibring, P., Flocke, F., Zheng, W., Toohey, D., Wennberg, P. O., Wiedinmyer, C., Mauldin, L., Fried, A., Richter, D., Walega, J., Jimenez, J. L., Adachi, K., Buseck, P. R., Hall, S. R., and Shetter, R.: Emissions from biomass burning in the Yucatan, Atmos. Chem. Phys., 9, 5785-5812, doi:10.5194/acp-9-5785-2009, 2009.

Zhang, Q., Alfarra, M. R., Wornsop, D. R., Allan, J. D., Coe, H., Canagaratna, M., and Jimenez, J. L.: Deconvolution and quantification of hydrocarbon-like and oxygenated organic aerosols based on aerosol mass spectrometry, Environ. Sci. Technol., 39, 4938-4952, 2005. 